OPEN ACCESS

Edited by:

Boris Rewald,

University of Natural Resources

and Life Sciences, Vienna, Austria

Reviewed by:

Eryuan Liang,

Chinese Academy of Sciences, China

Cristina Nabais,

University of Coimbra, Portugal

*Correspondence:

Gerhard Wieser

gerhard.wieser@uibk.ac.at

Specialty section:

This article was submitted to

Functional Plant Ecology,

a section of the journal

Frontiers in Plant Science

Received: 22 April 2016

Accepted: 22 May 2016

Published: 07 June 2016

Citation:

Wieser G, Oberhuber W, Gruber A, Leo $M$, Matyssek $R$ and Grams TEE

(2016) Stable Water Use Efficiency under Climate Change of Three

Sympatric Conifer Species at the Alpine Treeline.

Front. Plant Sci. 7:799

doi: 10.3389/fpls.2016.00799

\section{Stable Water Use Efficiency under Climate Change of Three Sympatric Conifer Species at the Alpine Treeline}

\author{
Gerhard Wieser ${ }^{1 *}$, Walter Oberhuber ${ }^{2}$, Andreas Gruber ${ }^{2}$, Marco Leo ${ }^{1}$, Rainer Matyssek ${ }^{3}$ \\ and Thorsten Erhard Edgar Grams ${ }^{3}$

\begin{abstract}
1 Department of Alpine Timberline Ecophysiology, Federal Research and Training Centre for Forests, Natural Hazards and Landscape, Innsbruck, Austria, ${ }^{2}$ Institute of Botany, Leopold-Franzens-Universität Innsbruck, Innsbruck, Austria,

${ }^{3}$ Ecophysiology of Plants, Department of Ecology and Ecosystem Management, Technische Universität München, Freising, Germany
\end{abstract}

The ability of treeline associated conifers in the Central Alps to cope with recent climate warming and increasing $\mathrm{CO}_{2}$ concentration is still poorly understood. We determined tree ring stable carbon and oxygen isotope ratios of Pinus cembra, Picea abies, and Larix decidua trees from 1975 to 2010. Stable isotope ratios were compared with leaf level gas exchange measurements carried out in situ between 1979 and 2007. Results indicate that tree ring derived intrinsic water-use efficiency (iWUE) of $P$. cembra, $P$. abies and $L$. decidua remained constant during the last 36 years despite climate warming and rising atmospheric $\mathrm{CO}_{2}$. Temporal patterns in $\Delta^{13} \mathrm{C}$ and $\Delta^{18} \mathrm{O}$ mirrored leaf level gas exchange assessments, suggesting parallel increases of $\mathrm{CO}_{2}$-fixation and stomatal conductance of treeline conifer species. As at the study site soil water availability was not a limiting factor iWUE remained largely stable throughout the study period. The stability in iWUE was accompanied by an increase in basal area increment (BAI) suggesting that treeline trees benefit from both recent climate warming and $\mathrm{CO}_{2}$ fertilization. Finally, our results suggest that iWUE may not change species composition at treeline in the Austrian Alps due to similar ecophysiological responses to climatic changes of the three sympatric study species.

\section{Keywords: stable isotopes, intrinsic water use efficiency, tree growth, climate change, treeline, Central Alps}

\section{INTRODUCTION}

High-altitude forest ecosystems at the timberline-treeline transition have raised concern as they may undergo significant alterations due to climate warming and changes in ground-level air chemistry (Holtmeier and Broll, 2007; Wieser et al., 2009). Dendroclimatological studies conducted within the treeline ecotone of the Central European Alps have shown radial stem growth to be limited by low summer temperature (Carrer and Urbinati, 2004; Oberhuber, 2004; Büntgen et al., 2005; Frank and Esper, 2005; Oberhuber et al., 2008). During recent decades, several authors report treeline-associated conifers to reflect increased radial growth, putatively related to climate warming (Graumlich et al., 1989; Peterson et al., 1990; Jacoby and D’Arrigo, 1997; Rolland and Florence-Schueller, 1998; Bunn et al., 2005). Moreover, increasing atmospheric $\mathrm{CO}_{2}$ concentration may act in concert with climate warming to increase carbon accumulation within the treeline ecotone (cf. Graumlich, 1991; Saurer et al., 1997; Duquesnay et al., 1998; Sidorova et al., 2009). 
Notwithstanding, reduced radial growth has been attributed to late-summer drought under increasing treeline temperature in the European Alps (Büntgen et al., 2006; Carrer and Urbinati, 2006; Oberhuber et al., 2008; Wieser et al., 2009).

Stable isotope ratios of carbon and oxygen, i.e., ${ }^{13} \mathrm{C} /{ }^{12} \mathrm{C}$ and ${ }^{18} \mathrm{O} /{ }^{16} \mathrm{O}$, respectively, may serve as dendrochronological proxies that facilitate mechanistic understanding of climaterelated influences on physiological processes such as leaf gas exchange and stem wood formation (Loader et al., 2007; Weigt et al., 2015; and further references therein). In plant organic matter, $\delta^{13} \mathrm{C}$ expressing the ${ }^{13} \mathrm{C} /{ }^{12} \mathrm{C}$ ratio in relation to an international standard (Pee Dee Belimnite) depends on variables such as leaf conductance for water vapor $\left(g_{\mathrm{w}}\right)$ that modify the net $\mathrm{CO}_{2}$ uptake rate $\left(A\right.$; Farquhar et al., 1989). In addition, $\delta^{13} C$ of plant organic matter $\left(\delta^{13} \mathrm{C}_{\mathrm{p}}\right)$ is a function of atmospheric $\delta^{13} \mathrm{C}$, which is accounted for by calculating discrimination of photosynthesis against ${ }^{13} \mathrm{C}\left(\Delta^{13} \mathrm{C}\right.$; Farquhar and Richards, 1984) in relation to intrinsic water-use efficiency (iWUE), i.e., the ratio of $A$ (rate of net $\mathrm{CO}_{2}$ fixation) versus $g_{\mathrm{w}}$ (leaf conductance for water vapor). For a review see Brugnoli and Farquhar (2000).

When analyzing $\delta^{13} C_{\mathrm{p}}$ alone, the impacts of $A$ (demand of $\mathrm{CO}_{2}$ ) and $g_{\mathrm{w}}$ (supply of $\mathrm{CO}_{2}$ ) on iWUE are difficult to separate (Saurer et al., 2008). The oxygen isotope ratio $\left(\delta^{18} O\right)$, however, may allow a distinction between biochemical and stomatal limitations of photosynthesis as it is not affected by the photosynthetic $\mathrm{CO}_{2}$ carboxylation but linked to $\mathrm{g}_{\mathrm{w}}$ (Barbour et al., 2000; Grams et al., 2007). It is, therefore, an ideal covariable to estimate to what degree photosynthesis and stomatal conductance modify $\delta^{13} C_{\mathrm{p}}$ (Scheidegger et al., 2000; Werner et al., 2012). Originally, this dual isotope approach was introduced for photosynthetic tissue and only recently tested conceptually for the interpretation of tree-ring data (Roden and Farquhar, 2012), although several critical points should be taken into account during interpretion. Among the most important issues that need to be considered are the facts that the $\delta^{18} \mathrm{O}$ of source and atmospheric water can vary spatially and temporarily and that post-photosynthetic and post-evaporative oxygen atom exchange processes could affect the initial leaf-level isotope signal (see below).

At the leaf level, $\delta^{18} \mathrm{O}$ of photoassimilates derive primarily from leaf water, typically being enriched in ${ }^{18} \mathrm{O}$ compared to the source water (i.e., xylem water) through evaporative enrichment at the site of transpiration. This enrichment is counteracted by the so-called Péclet effect and transpiratory leaf cooling (for a review see Barbour, 2007), which may result in the above mentioned negative correlation between $\delta^{18} O_{\mathrm{p}}$ and $g_{\mathrm{w}}$ (e.g., Barbour et al., 2000; Grams et al., 2007). However, to an extent that may depend on species and site conditions, the signal is dampend by oxygen exchange with source water during biomass formation at the stem level (Gessler et al., 2013). This causes, at least partially, a decoupling between oxygen isotopic signatures of photoassimilates and the tree ring organic matter. However, in a recent report Weigt et al. (2015) confirmed that information may be exploited to relate ecophysiological responses of trees to environmental changes for both total sapwood organic matter and extracted cellulose. In any case, it appears advisable to confirm interpretation from the dual isotope approach by gas exchange assessments whenever possible.

Previous tree-ring carbon isotope studies carried out in tropical, arid, Mediterranean, temperate and boreal forest ecosystems have identified an increase in iWUE over the past 40 years in response to increasing atmospheric $\mathrm{CO}_{2}$ concentration (Penuelas et al., 2011; Saurer et al., 2014) and just recently supported by tree-ring $\delta^{13} \mathrm{C}$ dynamic global vegetation models comparisons (DGVMs; Frank et al., 2015). Tree growth on the contrary, remained stable or even declined, suggesting local site conditions to override a potential $\mathrm{CO}_{2}$-induced increase in growth (Penuelas et al., 2011; Silva and Anand, 2013; Levesque et al., 2014). Increasing iWUE accompanied by a reduced productivity has been attributed to the combined effect of elevated $\mathrm{CO}_{2}$ and climate change-induced soil drying (Penuelas et al., 2011; Saurer et al., 2014).

The impact of the steadily increasing $\mathrm{CO}_{2}$ level and concurrent climate change, however, still awaits clarification for treeline-associated conifers in the Central Austrian Alps where low temperatures limit tree growth (Oberhuber, 2007; Wieser et al., 2009). At treeline in the Central Austrian Alps ample precipitation during the growing season prevails every third to fourth day on average (Wieser, 2012), so that soil water limitation stays absent, allowing trees to meet their water demand (Tranquillini, 1979; Mayr, 2007; Matyssek et al., 2009). Hence, whole-tree conductance stays high and mainly depends on the evaporative demand in terms of irradiance and vapor pressure deficit (Wieser, 2012). Therefore, we hypothesize that treeline trees passively respond to the increasing atmospheric $\mathrm{CO}_{2}$ level $\left(C_{\mathrm{a}}\right)$, so that their leaf-intercellular $\mathrm{CO}_{2}$ concentration $\left(C_{\mathrm{i}}\right)$ rises in parallel, while iWUE remains unchanged. The hypothesis was evaluated by stable carbon and oxygen isotope sampling and radial growth analysis over the past 36 years (1975-2010) in stems of mature Pinus cembra, Picea abies and Larix decidua trees growing at the treeline of Mt. Patscherkofel in the Central Tyrolean Alps. Observed long-term trends in $\delta^{13} C_{p}, \delta^{18} O_{p}$ in tree rings and iWUE were at least for some years compared with in situ leaf-level gas exchange data, assessed at the same study site between 1979 and 2007 in adult P. cembra and L. decidua trees. Results are discussed in view of tree response to climate warming at the treeline ecotone.

\section{MATERIALS AND METHODS}

\section{Study Site, Climatic Data, and Tree Species}

The study was conducted in a scattered stand at the lower edge of the treeline ecotone at $1950 \mathrm{~m}$ a.s.l. on Mt. Patscherkofel $\left(47^{\circ} 12^{\prime} 37^{\prime \prime} \mathrm{N}, 11^{\circ} 27^{\prime} 07^{\prime \prime} \mathrm{E}\right)$, south of Innsbruck, Austria. The site is characterized by a cool subalpine climate, the possibility of frost during the entire year and a continuous snow cover from October through April. We used monthly mean temperatures and monthly total precipitation from 1975 to 2010 from a weather station nearby (Klimahaus Research Station and Alpengarten; $1950 \mathrm{~m}$ a.s.l.) for our analysis. Mean annual precipitation averaged $878 \mathrm{~mm}$, with $58 \%$ falling during 
the growing season (May through September). Mean annual air temperature averaged $2.4^{\circ} \mathrm{C}$, with summer maxima of up to $27^{\circ} \mathrm{C}$ and winter minima of $-28^{\circ} \mathrm{C}$.

The geology of Mt. Patscherkofel is dominated by gneisses and schist. The soil at the study site is a haplic podzol, being a typical soil type of the treeline ecotone in the Central Tyrolean Alps (Neuwinger, 1972). The water holding capacity of the soil (at 5-65 $\mathrm{cm}$ depth) at saturation $(-0.001 \mathrm{MPa})$ averages 0.60 $\mathrm{m}^{3} \mathrm{~m}^{-3}$. Due to frequent precipitation during the growing season soil water potential rarely drops below $-0.01 \mathrm{MPa}$, approximating soil water contents above $0.35 \mathrm{~m}^{3} \mathrm{~m}^{-3}$ (Wieser, 2012; including the dry summer of 2003, unpublished data).

The stand is composed of the dominant tree species Pinus cembra, accounting for $84 \%$ of the tree population, and accompanied by Larix decidua (9\%) and Picea abies L. Karst (7\%) at some locations. Trees grew either as isolated trees or in groups of four to five. The distance between single trees or tree groups was 20-30 m. From 20 P. cembra trees cored at the lower edge of the treeline ecotone Oberhuber et al. (2008) derived an expressed signal population (EPS) value of 0.94 , reflecting a strong climate signal in the site chronology. From these trees we selected five trees which had the strongest correlation to the site specific mean tree-ring chronology, no missing rings, and regular ring boundaries. In addition we cored five dominant $P$. abies and $L$. decidua trees each to account for potential interspecific differences of the three associated treeline species. In 2010 the trees were $69 \pm 9$ years old, with stem heights averaging $12 \pm 1.3 \mathrm{~m}$. The stem diameter at breast height $(\mathrm{DBH})$ averaged $22 \pm 3.2 \mathrm{~cm}$.

\section{Tree Ring and Basal Stem Area Increment}

In fall 2010 we obtained two increment cores per trees at $\mathrm{DBH}$ using a 5-mm-diameter increment bore. For contrast enhancement of tree ring boundaries the cores were dried in the laboratory, non-permanently mounted on a holder, and the surface was prepared with a razor blade (Pilcher, 1990). Ring widths were measured to the nearest $1 \mu \mathrm{m}$ using a reflecting microscope (Olympus SZ61) and the software package TSAP WIN Scientific. Ring widths of both cores from each sample tree were averaged and individual tree ring chronologies were then checked for dating accuracy using the COFECHA software (Holmes, 1994; Grissino-Mayer, 2001). As ring width may be biased by a negative correlation with the time course during tree maturation, ring width was converted to basal stem area increment (BAI) according to:

$$
\mathrm{BAI}=3.14\left(R_{\mathrm{n}}^{2}-R_{\mathrm{n}-1}^{2}\right)
$$

where $R$ is stem radius inside tree bark and $\mathrm{n}$ is the year of tree ring formation (Fritts, 1976). Bark thickness was subtracted from stem radius. Finally BAI of each year were averaged over the five sample trees of each species.

\section{Stable Isotope Analysis}

$\delta^{13} C$ and $\delta^{18} O$ analyses for the years 1975-2010 were performed on the same cores as used for BAI assessment. Annual rings (early wood plus late wood) were cut exactly at ring boundaries by use of a scalpel and a reflecting microscope (Wild 308700). For each of the five study trees per species the two samples per tree ring were pooled and homogenized with a swing mill (Retsch MM301, Retsch Haan, Germany). In a subsample, we compared isotope signatures in bulk wood with those in cellulose for determining the necessity of cellulose extraction in our study trees. Cellulose extraction was performed using a modified version of the method of Brendel et al. (2000). The methodological comparison corroborated significant correlations in the cases of $\delta^{13} \mathrm{C}$ and $\delta^{18} \mathrm{O}$ (Figure 1) as reported earlier from coniferous and other tree species (Jaggi et al., 2002; Sohn et al., 2013) and is in accordance with a recent report (Weigt et al., 2015). On average, $\delta^{13} \mathrm{C}$ in cellulose was $1.0-1.1 \%$ higher than in bulk wood (Table 1), being smaller than 1.3-1.4\% found in Picea abies by Borella et al. (1998) and Sohn et al. (2013). Mean $\delta^{18} O$ in cellulose was 4.3-4.9\% higher than in bulk wood (Table 1) being somewhat lower than $5.9 \%$ in bulk wood of Picea abies (Sohn et al., 2013). Based on these findings and in accordance with a recent methodological study (Weigt et al., 2015), we used bulk wood samples rather than extracted cellulose for isotope analysis.

Regarding $\delta^{13} C, 2.0 \pm 0.02 \mathrm{mg}$ of homogenized samples were weighed into tin capsules each $(3.5 \times 5 \mathrm{~mm}$, IVA Analysentechnik e.K., Meerbush, Germany) and combusted to $\mathrm{CO}_{2}$ in an elemental analyzer (Eurovector EA3000) connected to an isotope ratio mass spectrometer (Isoprime, Elementar, Hanau, Germany). For $\delta^{18} \mathrm{O}$ analysis $0.7 \pm 0.05 \mathrm{mg}$ were weighed into silver capsules each $(3.5 \times 5 \mathrm{~mm}$, IVA Analysentechnik e.K., Meerbush, Germany) to obtain $\mathrm{CO}$ at $1,430^{\circ} \mathrm{C}$ in a high-temperature pyrolysis system (HTO, HekaTech, Wegberg, Germany) which was connected via an open-split interface (Conflo III; Finnigan MAT, Bremen, Germany) to an isotope ratio mass spectrometer (Delta Plus; Finnigan MAT, Bremen, Germany). Isotope abundances were expressed using the $\delta$-notation in $\%$ relative to the international standards:

$$
\delta_{\text {sample }}=\left(R_{\text {sample }} / R_{\text {standard }}-1\right) * 1000
$$

where $R_{\text {sample }}$ is the molar fraction of the ${ }^{13} \mathrm{C} /{ }^{12} \mathrm{C}$ or ${ }^{18} \mathrm{O} /{ }^{16} \mathrm{O}$ ratio of the sample, and $R_{\text {standard }}$ that of the international IAEA standards V-PDB for carbon and V-SMOW for O. The analytical precision was $<0.12 \%$ and $<0.28 \%$ regarding $\delta^{13} \mathrm{C}$ and $\delta^{18} \mathrm{O}$, respectively (expressed as standard deviation of the internal laboratory standard at the same sample mass).

\section{Isotope Discrimination and iWUE}

Tree ring specific $\delta^{13} C_{\text {tring }}$ were corrected for the progressive decline in atmospheric $\delta^{13} C_{\text {atm }}$ through calculating ${ }^{13} \mathrm{C}$ discrimination $\left(\Delta^{13} C\right)$ :

$$
\Delta^{13} C(\%)=\left(\delta^{13} C_{\text {atm }}-\delta^{13} C_{\text {tring }}\right) /\left(1+\delta^{13} C_{\text {tring }} / 1000\right)
$$

To this end, $\delta^{13} C_{\text {atm }}$ with its nearly linear time course during 1980 through $2010^{1}$ was extrapolated for the years 1975 through 1979. In a simplified model, Farquhar et al. (1982) related $\Delta^{13} C$

${ }^{1}$ www.scrippsco2.ucsd.edu/home 


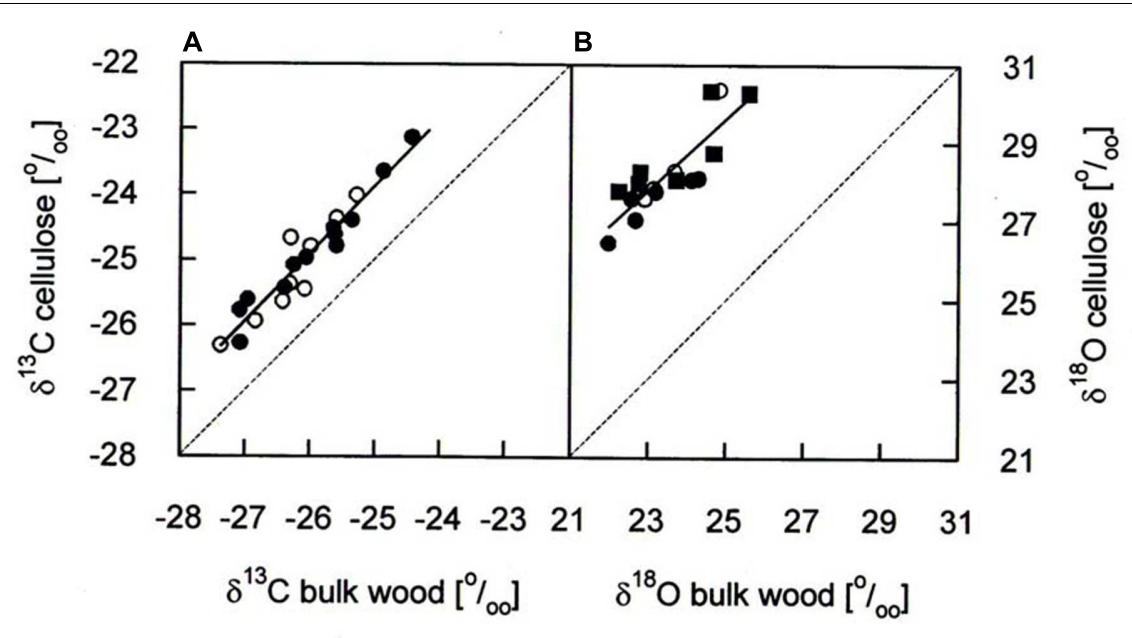

FIGURE 1 | Comparison of (A) $\delta^{13} C$ and (B) $\delta^{18} O$ in bulk wood and cellulose of annual growth rings of $P$. cembra (solid circle), $P$. abies (solid square) and $\boldsymbol{L}$. decidua (open circle). Dashed lines reflect the one-to-one lines for comparison and the solid lines correspond to the linear regression analyses of the data points: $\delta^{13} C: y=1.03 x+1.86, r^{2}=0.92, P<0.001, n=36 ; \delta^{18} O ; y=0.92 x+6.65, r^{2}=0.73, P<0.001, n=18$.

through plant physiological processes during $\mathrm{CO}_{2}$ fixation in $\mathrm{C} 3$ plants with the ratio of intercellular to ambient $\mathrm{CO}_{2}$ partial pressure $\left(C_{\mathrm{i}} / C_{\mathrm{a}}\right)$ :

$$
\Delta^{13} C=a+(b-a) * C_{\mathrm{i}} / C_{\mathrm{a}}
$$

where $a(=4.4 \%)$ refers to the slower diffusivity of ${ }^{13} \mathrm{CO}_{2}$ relative to ${ }^{12} \mathrm{CO}_{2}$ in air and $b(=27 \%)$ is the isotopic fractionation caused by enzymatic $\mathrm{C}$ fixation. $C_{\mathrm{a}}$ was obtained from published data ${ }^{2}$. It should be noted that $\Delta^{13} C$ is determined by the ratio of chloroplast to the ambient $\mathrm{CO}_{2}$ mole fraction $\left(C_{\mathrm{c}} / C_{\mathrm{a}}\right)$ rather than $C_{\mathrm{i}} / C_{\mathrm{a}}$, as used in equation 3 , making the here calculated value sensitive to mesophyll conductance ( $g_{\mathrm{m}}$; Seibt et al., 2008). The latter varies in accordance to changes in environmental conditions such as temperature, irradiance, water and $\mathrm{CO}_{2}$ availability (Flexas et al., 2008). Consequently using $C_{a}$ may be problematic if $g_{\mathrm{m}}$ to $\mathrm{CO}_{2}$ is not constant (Seibt et al., 2008). However, as information on mesophyll conductance of the three conifers under study is not available and published means of $g_{\mathrm{m}}$ would not improve results (Cernusak et al., 2013), we chose using the simplified linear model of Farquhar et al. (1982). Hence, iWUE, i.e., the ratio of the net carbon gain $(A)$ versus leaf conductance for water vapor $\left(g_{\mathrm{w}}\right)$, was calculated as follows:

$$
\mathrm{iWUE}=A / g_{\mathrm{w}}=C_{\mathrm{a}}\left(b-\Delta^{13} C / C_{\mathrm{a}}\right) / 1.6 *(b-a)
$$

where 1.6 is the ratio between the diffusivities of water vapor and $\mathrm{CO}_{2}$ in air.

Enrichment in ${ }^{18} \mathrm{O}$ in tree rings over source water $\left(\Delta^{18} \mathrm{O}\right)$, resulting from incorporation of ${ }^{18} \mathrm{O}$-enriched photoassimilates into stem biomass, was calculated from $\mathrm{d}^{18} \mathrm{O}$ of tree ring organic matter $\left(\delta^{18} O_{\text {tring }}\right)$ and precipitation $\left(\delta^{18} O_{\text {prep }}\right)$ according to:

$$
\Delta^{18} O(\%)=\left(\delta^{18} O_{\text {tring }}-\delta^{18} O_{\text {prep }}\right) /\left(1+\delta^{18} O_{\text {prep }} / 1000\right)
$$

${ }^{2}$ http://cdiac.ornl.gov/trends/co2/sio-mlo.html
TABLE $1 \mid \delta^{13} \mathrm{C}$ and $\delta^{18} \mathrm{O}$ difference between cellulose and bulk wood in annual growth rings of Pinus cembra, Picea abies and Larix decidua.

\begin{tabular}{lcc}
\hline Species & $\delta^{13} \boldsymbol{C}[\%]$ & $\delta^{18} \boldsymbol{O}[\%]$ \\
\hline P. cembra & $1.1 \pm 0.0$ & $4.4 \pm 0.4$ \\
P. abies & $1.0 \pm 0.1$ & $5.0 \pm 0.6$ \\
L. decidua & $1.1 \pm 0.1$ & $4.9 \pm 0.4$ \\
\hline
\end{tabular}

Precipitation is the only source of water on Mt. Patscherkofel and thus was assumed to reflect source water of trees. Furthermore, as there is evidence from a treeline in the Central Swiss Alps that mean values of $\delta^{18} O_{\text {prep }}$ and $\delta^{18} O$ of soil water do not differ significantly, although soil water $\delta^{18} O$ carries a distinct signal from snow melt water far into the growing season (Treydte et al., 2014), we used annual means of $\delta^{18} \mathrm{O}_{\text {prep }}$ sampled on top of Mt. Patscherkofel (2246 m a.s.l.) (Umweltbundesamt Austria; personal communication) approximately $300 \mathrm{~m}$ south of the selected study trees for our $\Delta^{18} \mathrm{O}$ calculation. We elevationally corrected $\delta^{18} O_{\text {prep }}$ by a factor of $0.17 \%$ per $100 \mathrm{~m}$ of elevation (Umweltbundesamt Austria; personal communication) which is considerably lower than the global mean of $0.28 \%$ per $100 \mathrm{~m}$ of elevation (Poage and Chamberlain, 2001).

\section{Leaf Level Gas Exchange Data}

To illustrate long term trends in foliar $\mathrm{CO}_{2}$ and $\mathrm{H}_{2} \mathrm{O}$ gas exchange we compiled published gas exchange data of mature, field grown $P$. cembra and L. decidua trees carried out at our study site between 1979 and 2007 (Table 2). Maximum net photosynthetic capacity at ambient $\mathrm{CO}_{2}\left(\mathrm{~A}_{\max }\right.$; sensu Larcher, 2001) was assessed of sun exposed twigs from the upper canopy. Employed in situ were thermoelectrically climate-controlled cuvettes (Walz, Effeltrich, Germany) or a portable exchange system (CIRAS 1, PP Systems, Hitchin, Hertfordshire, UK). For methodological details see publications given in Table 2 . 
TABLE 2 | A comparison of published maximum net photosynthetic capacity $\left(A_{\max }\right)$ and leaf conductance for water vapor of sun exposed shoots of mature Pinus cembra and Larix decidua trees at the lower end of the treeline ecotone on Mt. Patscherkofel.

\begin{tabular}{|c|c|c|c|c|c|}
\hline Species & Year & Measured trees & $A_{\max }\left[\mu \mathrm{mol} \mathrm{m}{ }^{-2} \mathrm{~s}^{-1}\right]$ & $g_{w}\left[\mathrm{mmol} \mathrm{m} \mathrm{m}^{-2} \mathrm{~s}^{-1}\right]$ & Reference \\
\hline P. cembra & 1979 & 1 & 3.4 & $\mathrm{nd}$ & Havranek, 1981 \\
\hline P. cembra & 2002 & 2 & $4.6 \pm 0.2$ & $\mathrm{nd}$ & Wieser et al., 2005 \\
\hline P. cembra & 2007 & 3 & $5.2 \pm 0.7$ & $\mathrm{nd}$ & Wieser et al., 2010 \\
\hline L. decidua & 1980 & 1 & 3.3 & 48 & Benecke et al., 1981 \\
\hline L. decidua & 1993 & 4 & $5.6 \pm 0.9$ & $85 \pm 14$ & Volgger, 1995 \\
\hline
\end{tabular}

n d, not determined.

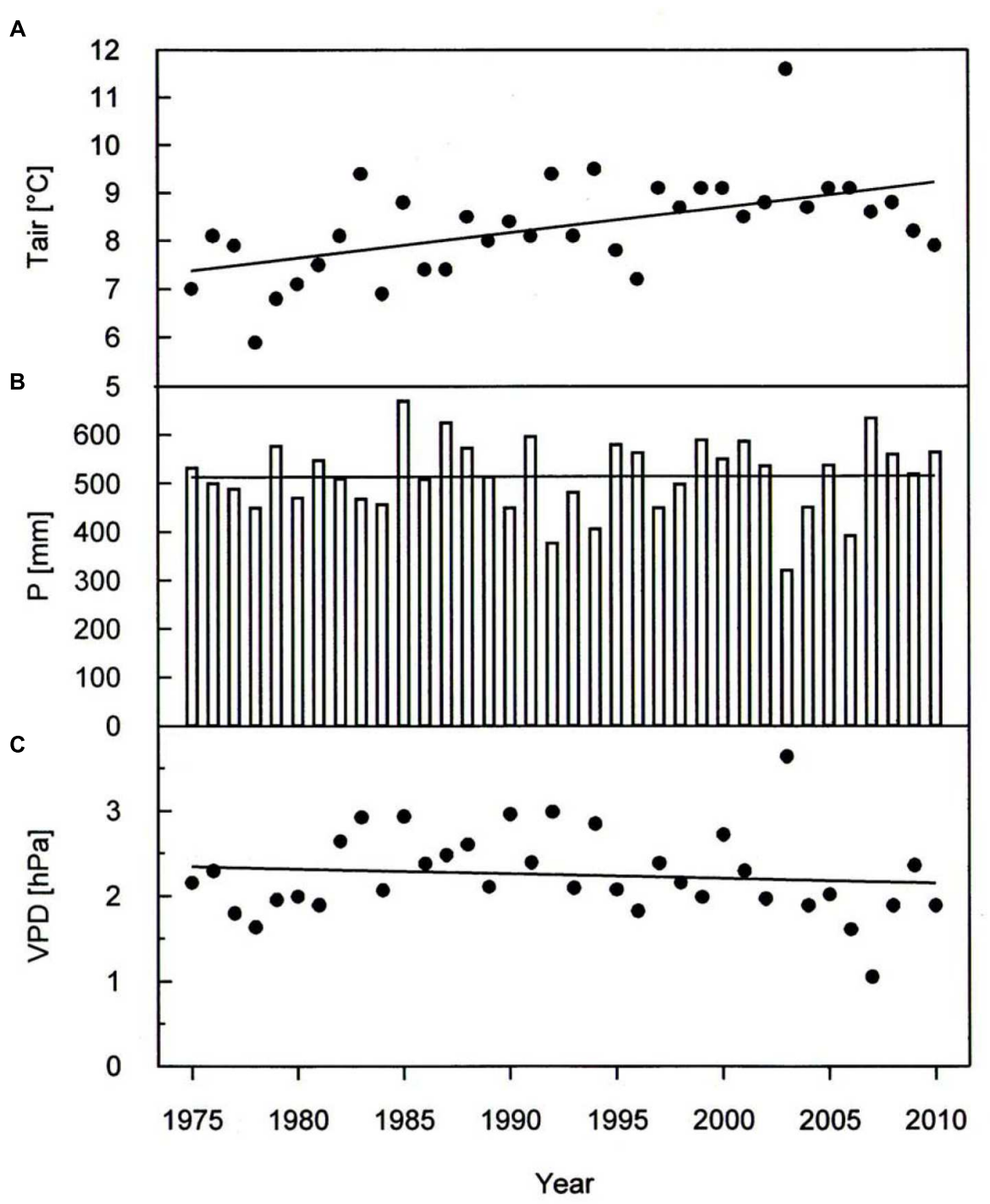

FIGURE 2 | Temporal variation in (A) growing season mean air temperature (Tair), (B) total growing season precipitation (P) and (C) growing season mean vapor pressure deficit (VPD) during the period 1975 throughout 2010. Data were fit by linear regression analysis: Tair: $y=0.053 x-97.0, r^{2}=0.30$, $P<0.001 ; P: y=0.075 x-365.3, r^{2}=0.00, P=0.95 ;$ VPD: $y=-0.055 x+13.3, r^{2}=0.01, P=0.49$.

\section{Statistical Analysis}

Temperature, precipitation, vapor pressure deficit, $\Delta{ }^{13} \mathrm{C}, \Delta{ }^{18} \mathrm{O}$, BAI, $C_{\mathrm{i}}, C_{\mathrm{i}} / C_{\mathrm{a}}$ and iWUE trends were calculated for the time period $1975-2010$ by least-squares linear regression analysis.
For a given variable, differences among trends (slopes) between $P$. cembra, $P$. abies and L. decidua were assessed by the twoslope comparison test (Zar, 1999). We used repeated measures ANOVA to detect significant differences in the mean values 


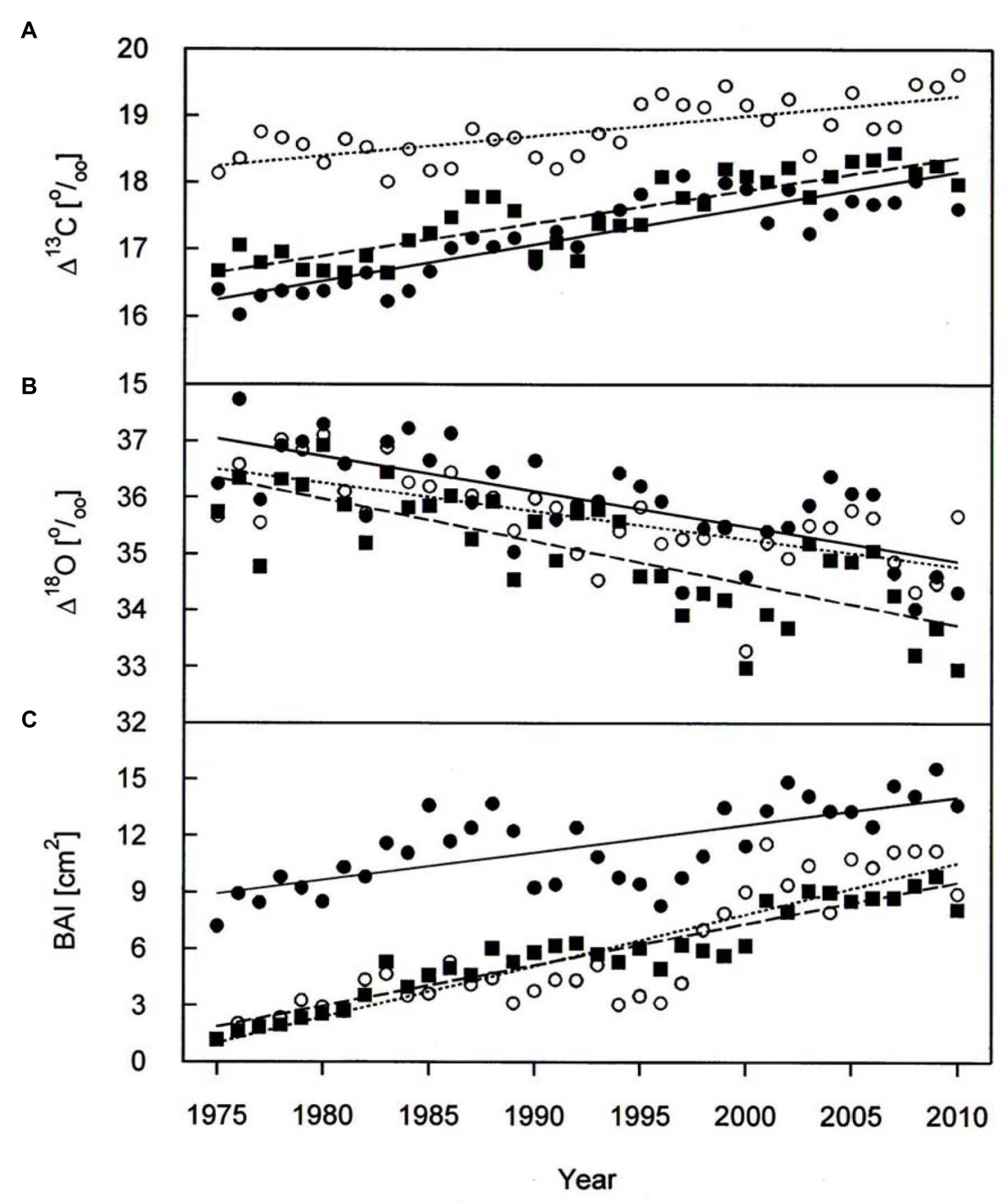

FIGURE $3 \mid \Delta^{13} C$ (A), $\Delta^{18} \mathrm{O}$ (B), and BAl (C) chronologies of $P$. cembra (solid circle, solid line), P. abies (solid square, dashed line) and $L$. decidua (open circle, dotted line) between 1975 and 2010. See Table 2 for regression information.

(1975-2010) of $\Delta^{13} C, \Delta^{18} O, B A I, C_{i}, C_{\mathrm{i}} / C_{\mathrm{a}}$ and iWUE of $P$. cembra, P. abies and L. decidua. Following Kunter et al. (2004) we used multiple least-squares linear regression models to assess the influence of atmospheric $\mathrm{CO}_{2}$ concentration $\left(C_{\mathrm{a}}\right)$ and mean growing season (May-Sep) air temperature $\left(\mathrm{T}_{\mathrm{veg}}\right)$ and their interactions (explanatory variables) on tree-ring variables. For assessing the climatic impact on tree ring variables (BAI, $\Delta^{13} C$, and $\Delta^{18} O$ ) statistical analyses were based on mean monthly air temperature $\left({ }^{\circ} \mathrm{C}\right)$ and total monthly precipitation (mm) throughout the study period (1975-2010). For each species Pearson's correlation coefficients between BAI, isotope chronologies and both climate variables were calculated from August of the year prior to growth to September of the growth year. All the statistical analysis were conducted by use of the SPSS 16 software package (SPSS. Inc. Chicago, IL, USA), and a probability level of $P<0.05$ was considered as statistically significant. As suggested by Sarris et al. (2013) we did not remove any age related trend from our tree-ring chronologies by conventional detrending procedures, thus avoiding the risk of removing any environmental signal or trend captured by our tree-ring series.

\section{RESULTS}

\section{Inter-annual Trends in Climate and Tree-Ring Indices}

A warming trend is reflected at our treeline site during the growing seasons $\left(0.50^{\circ} \mathrm{C}\right.$ per decade $\left.P<0.001\right)$ of $1975-2010$, without concurrent trends in precipitation and vapor pressure 
deficit (Figure 2). During the whole study period $\Delta^{13} \mathrm{C}$ and $\Delta^{18} \mathrm{O}$ chronologies were synchronized between the three studied species. In each species $\Delta^{13} \mathrm{C}$ increased over time (Figure $\mathbf{3 A}$; Table 3) whereas $\Delta^{18} \mathrm{O}$ decline (Figure 3B; Table 3). The increase in $\Delta^{13} C$ was accompanied by rising of $\mathrm{A}_{\max }$ for both $P$. cembra (1979-2007) and L. decidua (1980-1993) by about 50\%. Likewise, $g_{\mathrm{w}}$ increase by about $75 \%$ in L. decidua (Table 3 ).

The mean tree-ring $\Delta^{13} C$ was highest in L. decicua, although the increase was significantly higher in $P$. cembra and $P$. abies (Table 4). Temporal changes in $\Delta^{18} O$ by contrast, did not differ significantly between the tree species (Table 4). $P$. cembra showed the highest $\Delta^{18} O$ while $P$. abies presented the lowest $\Delta^{18} O$ and L. decidua displayed an intermediate mean (Table 4). On average, growth of $P$. cembra was significantly higher than growth of $P$. abies and L. decidua (Figure 3C; Table 4). During the whole study period all three species showed an increase in growth expressed as BAI, being significantly lower in $P$. cembra than P. abies, and L. decidua (Figure 3C; Table 4).
Paralleling atmospheric $\mathrm{CO}_{2}$ enhancement (Figure 4A), tree ring derived $C_{\mathrm{i}}$ increased from 1975 through 2010 from 180 to $234 \mu \mathrm{mol} \mathrm{mol}{ }^{-1}$ in $P$. cembra, from 185 to $227 \mu \mathrm{mol} \mathrm{mol}^{-1}$ in $P$. abies and from 213 to $256 \mu \mathrm{mol} \mathrm{mol}{ }^{-1}$ in L. decidua (Figure 4A; Table 2). Although species specific differences in the temporal change of $C_{\mathrm{i}}$ were not statistically significant different from each other, mean $C_{\mathrm{i}}$ was significantly lower in $P$. cembra and $P$. abies as compared to L. decidua (Table 4). Averaged over the study period $P$. cembra showed the lowest and $L$. decidua, the highest $C_{\mathrm{i}} / C_{\mathrm{a}}$, while the $C_{\mathrm{i}} / C_{\mathrm{a}}$ of $P$. abies was intermediate (Table 4). The increase in $C_{\mathrm{i}} / C_{\mathrm{a}}$ over time (Figure 4B; Table 3) was significantly higher in $P$. cembra and $P$. abies than in L. decidua (Table 4). In all the three species iWUE had remained stable during the study period (Figure 4C; Table 3). However, we observed statistically significant between species, with $P$. cembra showing the highest and Larix decidua showing the lowest iWUE averaged over the study period (Table 4).

TABLE 3 | Regression information for Figures 3 and 4.

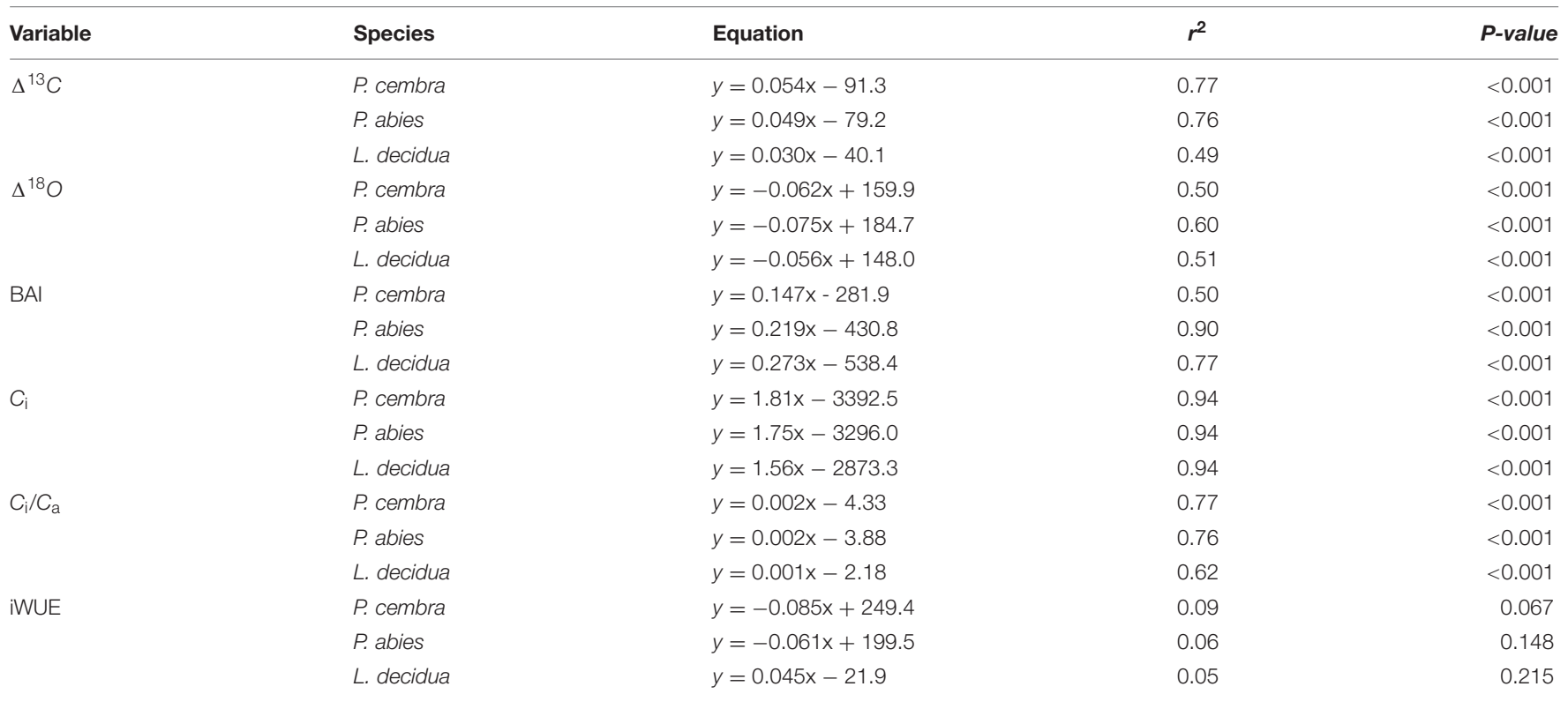

TABLE 4 | Tree-ring carbon isotope characteristics $\left(\Delta^{13} C, \Delta^{18} O, B A I, C_{i}, C_{i} / C_{a}\right.$, and iWUE) in $P$. cembra, $P$. abies, and $L$. decidua during the period 1975-2010.

\begin{tabular}{|c|c|c|c|c|c|c|}
\hline & \multicolumn{2}{|c|}{ P. cembra } & \multicolumn{2}{|c|}{$P$ abies } & \multicolumn{2}{|c|}{ L. decidua } \\
\hline$\Delta^{13} \mathrm{C}[\% 0]$ & $1.9^{\mathrm{a}}$ & $17.2 \pm 0.7^{\mathrm{a}}$ & $1.8^{\mathrm{a}}$ & $17.3 \pm 0.6^{a}$ & $1.1^{b}$ & $18.8 \pm 0.484^{b}$ \\
\hline$\Delta^{18} \mathrm{O}[\% 0]$ & $-2.2^{a}$ & $35.9 \pm 0.9^{a}$ & $-2.7^{a}$ & $35.0 \pm 1.052^{b}$ & $-2.0^{\mathrm{a}}$ & $35.6 \pm 0.883^{c}$ \\
\hline $\mathrm{BAl}\left[\mathrm{cm}^{2}\right]$ & $5.3^{\mathrm{a}}$ & $7.6 \pm 3.8^{a}$ & $7.9^{\mathrm{b}}$ & $5.7 \pm 2.473^{b}$ & $9.8^{b}$ & $5.8 \pm 3.3^{b}$ \\
\hline$C_{\mathrm{i}}\left[\mu \mathrm{mol} \mathrm{mol}{ }^{-1}\right]$ & $65.2^{\mathrm{a}}$ & $203.5 \pm 19.6^{a}$ & $63.06^{\mathrm{a}}$ & $208.5 \pm 19^{a}$ & $56.2^{\mathrm{a}}$ & $228.8 \pm 16.9^{b}$ \\
\hline
\end{tabular}

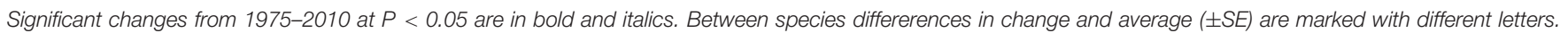

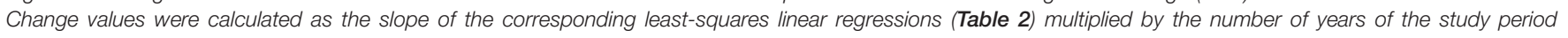
1975-2010 (=36). 


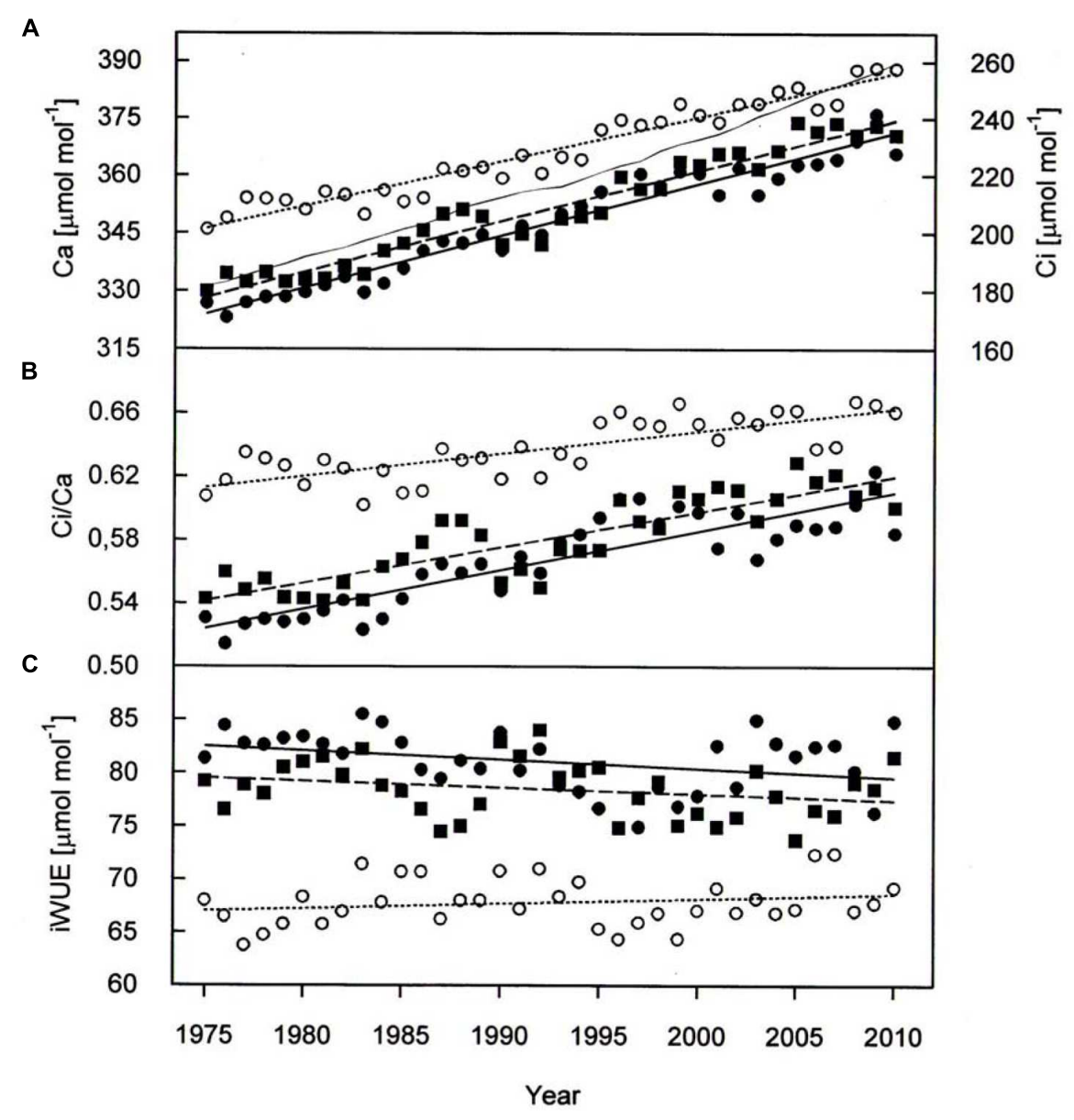

FIGURE 4 | (A) Ambient armospheric $\mathrm{CO}_{2}$ concentration ( $C_{a}$, thin solid line) $C_{\mathrm{i}},(\mathbf{B}) C_{\mathrm{i}} / C_{a}$, and $(\mathbf{C})$ iWUE chronologies of $P$. cembra (solid circle, solid line), P. abies (solid square, dashed line) and $L$. decidua (open circle, dotted line) between 1975 and 2010. See Table 2 for regression information.

\section{Effects $C_{\mathrm{a}}$ and $\mathrm{T}_{\text {veg }}$ on $\Delta^{13} \mathrm{C}, \Delta^{18} \mathrm{O}$, BAl, $C_{\mathrm{i}}, C_{\mathrm{i}} / C_{\mathrm{a}}$ and iWUE}

Multiple linear regression analysis show that $\Delta{ }^{13} \mathrm{C}$ and $\Delta^{18} \mathrm{O}$ of all species significantly increased with increasing ambient $\mathrm{CO}_{2}$ concentration $\left(C_{\mathrm{a}}\right)$ while growing season mean air temperature $\left(\mathrm{T}_{\mathrm{veg}}\right)$ had no effect on $\Delta^{13} \mathrm{C}$ and on $\Delta^{18} \mathrm{O}$ (Table 5). Growth (BAI) of P. cembra, and P. abies significantly increased with increasing $C_{\mathrm{a}}$ and $\mathrm{T}_{\mathrm{veg}}$. L. decidua presented a significant increase in BAI at increasing $C_{\mathrm{a}}$ without any response to $\mathrm{T}_{\mathrm{veg}}$ (Table 5). For all species we found a significant increase in $C_{\mathrm{i}}$ and $C_{\mathrm{i}} / C_{\mathrm{a}}$ at higher $C_{\mathrm{a}}$ but not at higher $\mathrm{T}_{\text {veg }}$ (Table 5). iWUE of P. cembra, P. abies, and L. decidua, however, did not significantly respond to increasing $C_{\mathrm{a}}$ and $\mathrm{T}_{\mathrm{veg}}$ (Table 5).

\section{$\Delta^{13} C, \Delta^{18} \mathrm{O}$, and BAl Response to Climate (Climate-Growth Relationships)}

Climate-response relationships of $\Delta{ }^{13} C, \Delta{ }^{18} O$, and BAI differed both in time and in signal strength (Figures 5 and $\mathbf{6}$ ). In all three species $\Delta{ }^{13} C$ was significantly positive correlated with April throughout June temperatures (Figure $\mathbf{5 A}$ ) and significantly negative correlated with January precipitation (Figure 6A). Previous-year August and October temperature also favored $\Delta{ }^{13} C$ in $P$. cembra and in $P$. abies, respectively (Figure $\mathbf{5 A}$ ), whereas previous- and current-year August precipitation did so in P. abies (Figure 6A).

The effects of temperature and precipitation on $\Delta^{18} \mathrm{O}$ were clearly in opposite directions (Figures 5B and 6B). In all the three species tree-ring $\Delta^{18} \mathrm{O}$ was negative correlated to air temperature from April to June of the current year and significantly positive correlated to previous-year December temperature (Figure 5B) as well as to January precipitation (Figure 6B). From Figure 5B, previous- year August temperature had a negative correlation with $L$. decidua and current-year January temperature showed a negative correlation with $L$. decidua. Previous-year November and current-year March precipitation showed a negative correlation with $\Delta^{18} O$ in $L$. decidua, as did June precipitation in P. cembra (Figure 6B).

We also found significant positive correlations between BAI and temperature during April, May, and June in 
TABLE 5 | Summary of multiple linear regression models fitted to explain inter-annual changes (1975-2010) in $\Delta^{13} C, \Delta^{18} \mathrm{O}, \mathrm{BAI}, C_{\mathrm{i}}, C_{\mathrm{i}} / \mathrm{C}_{\mathrm{a}}$, and iWUE of $P$. cembra, $P$. abies, and $L$. decidua in response to atmospheric $\mathrm{CO}_{2}$ concentration $\left(C_{\mathrm{a}}\right)$ and mean growing season (May-Sep) air temperature $\left(\mathrm{T}_{\mathrm{veg}}\right)$.

\begin{tabular}{|c|c|c|c|c|c|c|c|}
\hline Species & Variable & coefficient & $S E$ & $\beta$ & $t$-value & $\begin{array}{c}r \text {-value } \\
\text { partial }\end{array}$ & $P$-value \\
\hline \multicolumn{8}{|l|}{$\Delta^{13} C$} \\
\hline P. abies & $\begin{array}{c}\text { Intercept } \\
\boldsymbol{C}_{\mathbf{a}} \\
\mathrm{T}_{\text {veg }}\end{array}$ & $\begin{array}{r}6.797 \\
0.031 \\
-0.064\end{array}$ & $\begin{array}{l}1.054 \\
0.003 \\
0.058\end{array}$ & $\begin{array}{r}0.925 \\
-0.111\end{array}$ & $\begin{array}{r}6.446 \\
9.187 \\
-1.106\end{array}$ & $\begin{array}{r}0.848 \\
-0.189\end{array}$ & $\begin{array}{r}<0.001 \\
<0.001 \\
0.277\end{array}$ \\
\hline L. decidua & $\begin{array}{c}\text { Intercept } \\
\boldsymbol{C}_{\mathbf{a}} \\
\mathrm{T}_{\text {veg }}\end{array}$ & $\begin{array}{r}11.883 \\
0.023 \\
-0.164\end{array}$ & $\begin{array}{l}1.027 \\
0.003 \\
0.056\end{array}$ & $\begin{array}{r}0.901 \\
-0.378\end{array}$ & $\begin{array}{r}11.572 \\
6.917 \\
-2.900\end{array}$ & $\begin{array}{r}0.769 \\
-0.451\end{array}$ & $\begin{array}{r}<0.001 \\
<0.001 \\
0.007\end{array}$ \\
\hline \multicolumn{8}{|l|}{$\Delta^{18} O$} \\
\hline P. cembra & $\begin{array}{c}\text { Intercept } \\
\boldsymbol{C}_{\mathbf{a}} \\
\mathrm{T}_{\text {veg }}\end{array}$ & $\begin{array}{r}49.624 \\
-0.039 \\
0.054\end{array}$ & $\begin{array}{l}2.360 \\
0.008 \\
0.130\end{array}$ & $\begin{array}{r}-0.742 \\
0.060\end{array}$ & $\begin{array}{r}21.030 \\
-5.158 \\
0.419\end{array}$ & $\begin{array}{r}-0.668 \\
0.073\end{array}$ & $\begin{array}{r}<0.001 \\
<0.001 \\
0.678\end{array}$ \\
\hline L. decidua & $\begin{array}{c}\text { Intercept } \\
\boldsymbol{C}_{\mathbf{a}} \\
\mathrm{T}_{\mathrm{veg}}\end{array}$ & $\begin{array}{l}45.863 \\
-0.026 \\
-0.094\end{array}$ & $\begin{array}{l}2.219 \\
0.007 \\
0.122\end{array}$ & $\begin{array}{l}-0.574 \\
-0.120\end{array}$ & $\begin{array}{l}20.671 \\
-3.671 \\
-0.768\end{array}$ & $\begin{array}{l}-0.538 \\
-0.0132\end{array}$ & $\begin{array}{r}<0.001 \\
0.001 \\
0.448\end{array}$ \\
\hline \multicolumn{8}{|l|}{ BAI } \\
\hline P. cembra & $\begin{array}{c}\text { Intercept } \\
\boldsymbol{C}_{\mathrm{a}} \\
\boldsymbol{T}_{\text {veg }}\end{array}$ & $\begin{array}{r}-19.964 \\
0.079 \\
0.357\end{array}$ & $\begin{array}{l}5.482 \\
0.018 \\
0.301\end{array}$ & $\begin{array}{l}0.627 \\
0.166\end{array}$ & $\begin{array}{r}-3.642 \\
4.472 \\
1.184\end{array}$ & $\begin{array}{l}0.614 \\
0.202\end{array}$ & $\begin{array}{r}0.001 \\
<0.001 \\
<0.001\end{array}$ \\
\hline P. abies & $\begin{array}{c}\text { Intercept } \\
\boldsymbol{C}_{\mathrm{a}} \\
\boldsymbol{T}_{\text {veg }}\end{array}$ & $\begin{array}{r}-40.583 \\
0.120 \\
0.401\end{array}$ & $\begin{array}{l}2.643 \\
0.009 \\
0.145\end{array}$ & $\begin{array}{l}0.855 \\
0.169\end{array}$ & $\begin{array}{r}-15.354 \\
13.990 \\
2.761\end{array}$ & $\begin{array}{l}0.925 \\
0.433\end{array}$ & $\begin{array}{r}<0.001 \\
<0.001 \\
0.009\end{array}$ \\
\hline L. decidua & $\begin{array}{c}\text { Intercept } \\
\boldsymbol{C}_{\mathbf{a}} \\
\mathrm{T}_{\mathrm{veg}}\end{array}$ & $\begin{array}{r}-53.532 \\
0.159 \\
0.272\end{array}$ & $\begin{array}{l}5.382 \\
0.017 \\
0.296\end{array}$ & $\begin{array}{l}0.844 \\
0.085\end{array}$ & $\begin{array}{r}-9.947 \\
9.128 \\
0.919\end{array}$ & $\begin{array}{l}0.846 \\
0.158\end{array}$ & $\begin{array}{r}<0.001 \\
<0.001 \\
0.365\end{array}$ \\
\hline L. decidua & $\begin{array}{c}\text { Intercept } \\
\boldsymbol{C}_{\mathbf{a}} \\
\mathrm{T}_{\text {veg }}\end{array}$ & $\begin{array}{r}-113.938 \\
0.987 \\
-1.313\end{array}$ & $\begin{array}{c}14.692 \\
0.048 \\
0.808\end{array}$ & $\begin{array}{r}1.011 \\
-0.079\end{array}$ & $\begin{array}{l}-7.755 \\
20.726 \\
-1.625\end{array}$ & $\begin{array}{r}0.964 \\
-0.272\end{array}$ & $\begin{array}{r}<0.001 \\
<0.001 \\
0.114\end{array}$ \\
\hline \multicolumn{8}{|l|}{$C_{\mathrm{i}} / C_{\mathrm{a}}$} \\
\hline P. cembra & $\begin{array}{c}\text { Intercept } \\
\boldsymbol{C}_{\mathbf{a}} \\
\mathrm{T}_{\text {veg }}\end{array}$ & $\begin{array}{r}0.037 \\
0.002 \\
-0.003\end{array}$ & $\begin{array}{l}0.054 \\
0.000 \\
0.003\end{array}$ & $\begin{array}{r}0.906 \\
-0.087\end{array}$ & $\begin{array}{r}0.680 \\
8.752 \\
-0.843\end{array}$ & $\begin{array}{r}0.836 \\
-0.145\end{array}$ & $\begin{array}{r}0.501 \\
<0.001 \\
0.405\end{array}$ \\
\hline P. abies & $\begin{array}{c}\text { Intercept } \\
\boldsymbol{C}_{\mathbf{a}} \\
\mathrm{T}_{\text {veg }}\end{array}$ & $\begin{array}{r}0.087 \\
0.001 \\
-0.003\end{array}$ & $\begin{array}{l}0.049 \\
0.000 \\
0.003\end{array}$ & $\begin{array}{r}0.918 \\
-0.096\end{array}$ & $\begin{array}{r}1.795 \\
9.118 \\
-0.995\end{array}$ & $\begin{array}{r}0.864 \\
-0.164\end{array}$ & $\begin{array}{r}0.082 \\
<0.001 \\
0.347\end{array}$ \\
\hline L decidua & $\begin{array}{c}\text { Intercept } \\
\boldsymbol{C}_{\mathbf{a}} \\
\mathrm{T}_{\text {veg }}\end{array}$ & $\begin{array}{r}0.321 \\
0.001 \\
-0.004\end{array}$ & $\begin{array}{l}0.041 \\
0.000 \\
0.002\end{array}$ & $\begin{array}{c}0.887 \\
-0.0193\end{array}$ & $\begin{array}{r}7.817 \\
7.240 \\
-1.574\end{array}$ & $\begin{array}{r}0.783 \\
-0.264\end{array}$ & $\begin{array}{r}<0.001 \\
<0.001 \\
0.125\end{array}$ \\
\hline \multicolumn{8}{|l|}{ iWUE } \\
\hline P. cembra & $\begin{array}{c}\text { Intercept } \\
\boldsymbol{C}_{\mathbf{a}} \\
T_{\text {veg }}\end{array}$ & $\begin{array}{r}98.731 \\
-0.062 \\
0.534\end{array}$ & $\begin{array}{l}9.964 \\
0.032 \\
0.548\end{array}$ & $\begin{array}{r}-0.372 \\
0.189\end{array}$ & $\begin{array}{r}9.909 \\
-1.915 \\
0.974\end{array}$ & $\begin{array}{r}-0.316 \\
0.161\end{array}$ & $\begin{array}{r}<0.001 \\
0.064 \\
0.337\end{array}$ \\
\hline P. abies & $\begin{array}{c}\text { Intercept } \\
C_{\mathrm{a}} \\
T_{\text {veg }}\end{array}$ & $\begin{array}{r}92.903 \\
-0.053 \\
0.534\end{array}$ & $\begin{array}{l}9.052 \\
0.029 \\
0.534\end{array}$ & $\begin{array}{r}-0.351 \\
0.210\end{array}$ & $\begin{array}{r}10.263 \\
-1.798 \\
1.072\end{array}$ & $\begin{array}{r}-0.299 \\
0.184\end{array}$ & $\begin{array}{r}<0.001 \\
0.081 \\
0.291\end{array}$ \\
\hline
\end{tabular}


TABLE 5 | Continued

\begin{tabular}{|c|c|c|c|c|c|c|c|}
\hline Species & Variable & coefficient & $S E$ & $\beta$ & $t$-value & $\begin{array}{c}r \text {-value } \\
\text { partial }\end{array}$ & $P$-value \\
\hline \multirow[t]{3}{*}{ L. decidua } & Intercept & 59.644 & 7.661 & & 7.785 & & $<0.001$ \\
\hline & $C_{a}$ & 0.007 & 0.025 & 0.052 & 0.270 & 0.047 & 0.789 \\
\hline & $\mathrm{T}_{\text {veg }}$ & 0.695 & 0.421 & 0.317 & 1.650 & 0.276 & 0.108 \\
\hline
\end{tabular}

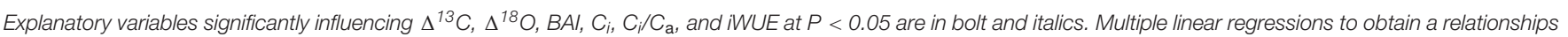

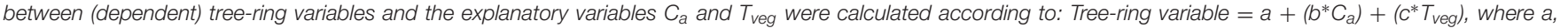

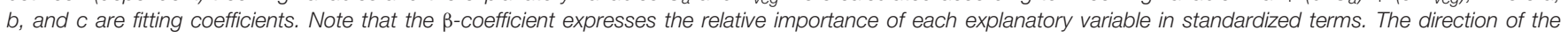

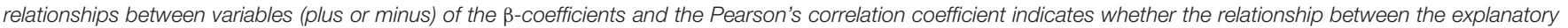
variable and the dependent variable is positive or negative.

P. cembra, P. abies, and L. decidua (Figure 5C). Currentyear August temperature also favored BAI in $L$. decidua and $P$. abies, and also previous-year October temperature in $P$. abies (Figure 5C). The correlations between BAI and precipitation were weak, except for significant positive correlations in February and current-year August in P. cembra and a significant negative correlation in January in $P$. abies (Figure 6C).

\section{DISCUSSION}

Similar growth and $\Delta^{13} C$, and $\Delta \delta^{18} O$ responses were found over time in $P$. cembra, $P$. abies and L. decidua at the lower edge of the treeline ecotone in the central Austrian Alps. From 1975 throughout 2010 the three species increased $\Delta^{13} C$ and BAI, while $\Delta^{18} \mathrm{O}$ showed a declining trend. Apparently, underlying response mechanisms were similar across the three studied species.

Our observed correlations for temperature and precipitation for $\Delta^{13} C$ and $\Delta^{18} O$ (Figures 5 and 6) are consistent with results reported for oak and pine trees at temperate sites in Switzerland (Saurer et al., 2008). Weather conditions prevailing during April through June predominantly were responsible for variations in tree-ring $\Delta^{13} C, \Delta^{18} \mathrm{O}$, and BAI of $P$. cembra, $P$. abies, and L. decidua. We found positive correlations between April to June temperatures and $\Delta^{13} C . \Delta^{13} C$ is strongly affected by net $\mathrm{CO}_{2}$ uptake rates, which at treeline are governed by both photon flux density and temperature (Treydte et al., 2001; McCarrol and Pawellek, 2004; Kress et al., 2011) as well as enhanced plant transpiration (Liu et al., 2015). Moreover, at our study site in situ net photosynthetic capacity of sun exposed twigs from the upper canopy of mature P. cembra and L. decidua trees measured under clear summer days also tended to increase between 1979 and 2007 (Table 2), which might be attributed to both the observed increase in atmospheric $\mathrm{C}_{\mathrm{a}}$ and $\mathrm{T}_{\mathrm{air}}$. Additionally, the temperature optimum of $\mathrm{A}_{\max }$ for $P$. cembra increased from $12.5^{\circ} \mathrm{C}$ in 1956 (Pisek et al., 1969,1973 ) to $15.0^{\circ} \mathrm{C}$ in 2002 (Wieser, 2004) and to $17.1^{\circ} \mathrm{C}$ in 2007 (Wieser et al., 2010), matching the observed increase in mean growing season air temperature of $0.9^{\circ} \mathrm{C}$ per decade (Figure 2). An increase in net photosynthetic rates under elevated $\mathrm{CO}_{2}$ was also observed in P. mugo and L. decidua after nine years of free-air $\mathrm{CO}_{2}$ enrichment at the Swiss treeline (Dawes et al., 2013; Streit et al., 2014). Three years of ecosystem warming also increased carbon uptake of Pinus cembra at treeline in the Austrian Alps (Wieser et al., 2015).

Our precipitation signals suggest that trees do not suffer from moisture stress. Indeed the observed declining trend $\Delta^{18} \mathrm{O}$ and the strong negative correlations between $\Delta^{18} \mathrm{O}$ and growing season precipitation is consistent with the physiological isotopic responses (Barbour and Farquhar, 2000), suggesting that stomatal conductance is increased during the study period. Although a leaf physiological signal in $\delta^{18} O$ will be dampened at the level of tree rings due to oxygen exchange with source water during cellulose biosynthesis, impact of gw on ${ }^{18} \mathrm{O}$ in tree rings may be still detectable, even in whole wood analyses (Weigt et al., 2015). Ecosystem warming accompanied by unchanged VPD also increased $g_{\mathrm{w}}$ and hence also transpiration in boreal Picea abies (Bergh and Linder, 1999), Pinus sylvestris (Kellomäki and Wang, 1998), Picea mariana (Van Herk et al., 2011), Pinus cembra at treeline (Wieser et al., 2015), and Populus deltoides (Barron-Gafford et al., 2007). Thus, it seems that in cold environments under non-limiting water availability increasing temperatures counteract the diminishing effect of rising $\mathrm{CO}_{2}$ on leaf conductance (Saurer et al., 2014).

The observed positive correlations between BAI and AprilJune temperatures are also reflected in wood formation. At the study site wood formation of larch, spruce and pine generally starts in May, reaches its maximum in June, and terminates in August (Havranek, 1981; Loris, 1981; Gruber et al., 2009). Beside summer temperatures (Figure 5C) other climatic variable like winter and August precipitation (Figure 6C) are also known to influence radial growth at treeline as shown for P. cembra by Oberhuber (2004), reflecting minor soil water effects on tree growth at treeline (Tranquillini, 1979; Wieser, 2004). Although treeline trees are saturated with carbohydrates (Gruber et al., 2011), growth of trees at treeline is primarily affected by temperature dependent carbon sink activity during tissue formation (Hoch and Körner, 2003, 2012). The observed increase in BAI (Figure 3C) suggests that our treeline trees benefit from climate warming, although effects of $\mathrm{CO}_{2}$ fertilization on growth may not completely ruled out (Table 5). Four years of experimental air warming with open-top-chambers also stimulated radial growth of Picea glauca seedlings at the subarctic treeline in southwest Yukon, Canada (Danby and Hik, 2007). Thus, when growth is stimulated and there is plenty of water $g_{\mathrm{w}}$ can increase as indicated by a decline in $\Delta^{18} O$ (Figure 3B) along with increasing $A$, resulting in a constant iWUE (Figure 4C). 


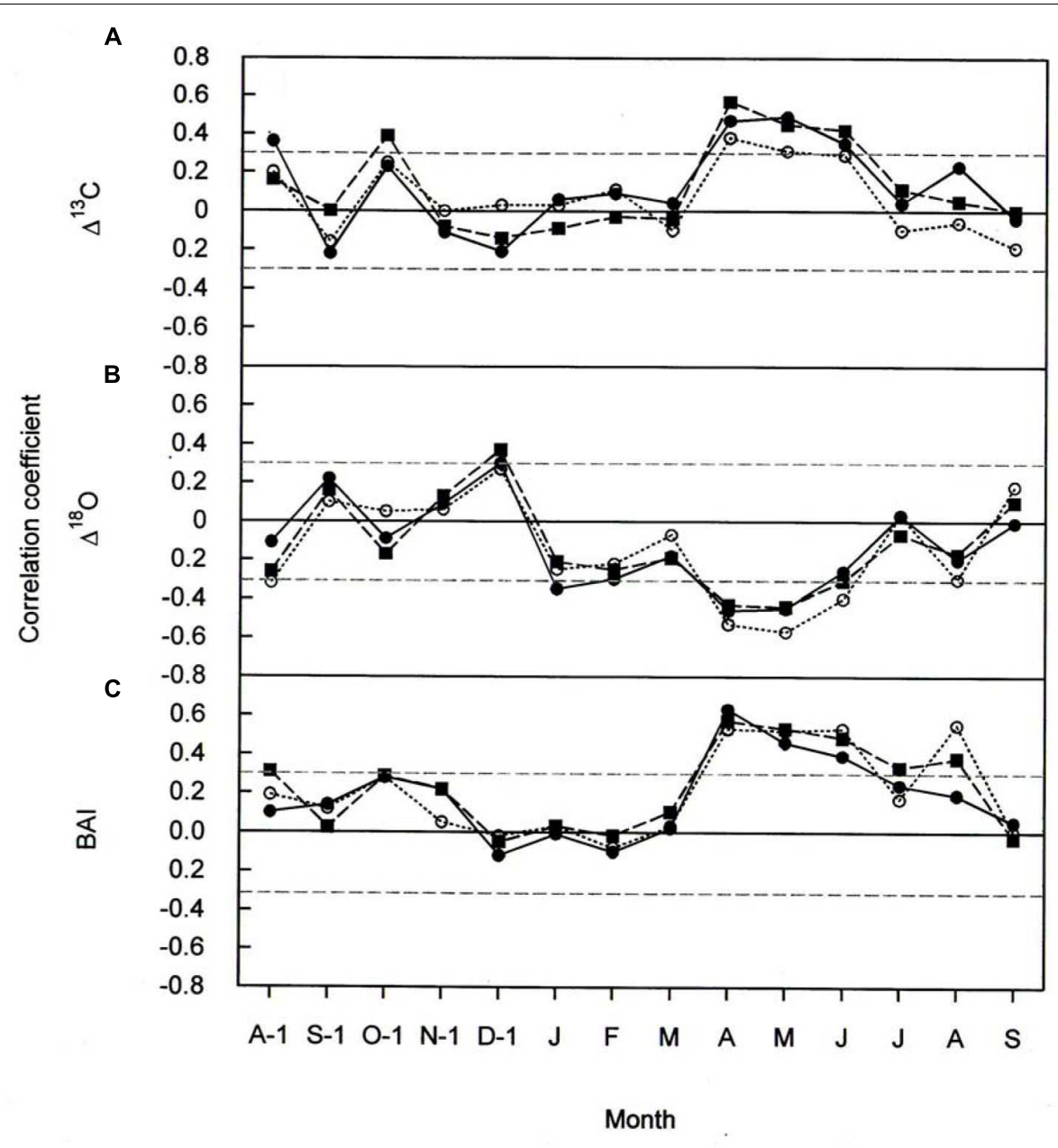

FIGURE 5 | Pearson correlation coefficients between (A) $\Delta^{13} C$ (B) $\Delta^{18} O$, and (C) BAI, and monthly mean temperature for $P$. cembra (solid circle, solid line), $P$. abies (solid square, dashed line) and $L$. decidua (open circle, dotted line) between $\mathbf{1 9 7 5}$ and $\mathbf{2 0 1 0}$. Horizontal gray lines indicates $P<0.05$.

Elevated atmospheric $\mathrm{CO}_{2}$ is expected to affect plant carbonwater relationships, as a decline in stomatal conductance is often observed when plants are exposed to elevated $\mathrm{CO}_{2}$ (Battipaglia et al., 2013). If stomatal conductance declines under increasing $\mathrm{CO}_{2}$ in combination with an increased or unchanged carbon assimilation, this will decrease the $C_{\mathrm{i}}$ to $C_{\mathrm{a}}$ ratio and thus decrease $\Delta{ }^{13} C$. Conversely, in all three study species $\Delta{ }^{13} C$ increased from 1975 throughout 2010, while tree-ring derived iWUE remained stable (Figure 4C) although ambient $\mathrm{CO}_{2}$ concentration increased by $60 \mu \mathrm{mol} \mathrm{mol}{ }^{-1}$ (Figure 2B). The stability of iWUE resulted as $C_{\mathrm{i}}$ drifted upward paralleling the rise in $C_{\mathrm{a}}$ (Figure 2B). Likewise, in Picea schrenkiana at treeline in the western Tianshan Mountains in China iWUE remained also unchanged from 1985 to 2010 (Wu et al., 2015). No change in iWUE (i.e., homeostasis) over the last 100 years was also reported for three conifer species in the Selkirk Range (Rocky Mountains, Idaho, ID, USA) by Marshall and Monserud (1996). Other studies by contrast observed a $20 \%$ increase in iWUE from the 1960 throughout 2000 in mature trees in tropical, arid, Mediterranean, wet temperate and boreal forests distributed through Europe, Asia, Africa, America, and Oceania (Penuelas et al., 2011; Saurer et al., 2014; Frank et al., 2015). In these latter studies, increasing iWUE was attributed to the combined effect of increasing $\mathrm{CO}_{2}$ and climate change-induced soil drying that reduced stomatal aperture. Soil drought can be ruled out along the treeline ecotone of the Central Alps (Mayr, 2007; Wieser, 2012). Occurrence of soil drought strongly depends on site conditions such as precipitation patterns, water holding capacity of the soil, and evaporative demand. Ample precipitation and moderate evaporative demand in general cause soil water availability to be sufficiently high to meet the trees' water demand at treeline in the Central Tyrolean Alps (Mayr, 2007; Wieser et al., 2009). As a consequence, treeline trees are rarely forced to restrict transpiration (Tranquillini, 1979; Benecke et al., 1981; Matyssek et al., 2009; Wieser and Leo, 2012; Wieser et al., 2014, 2015). Given the ample soil water availability whole-tree conductance of P. cembra, P. abies, and L. decidua remains high for $\mathrm{CO}_{2}$ uptake because leaf conductance for water vapor depends only on the evaporative demand driven by irradiance and vapor pressure deficit (Wieser, 2012). 


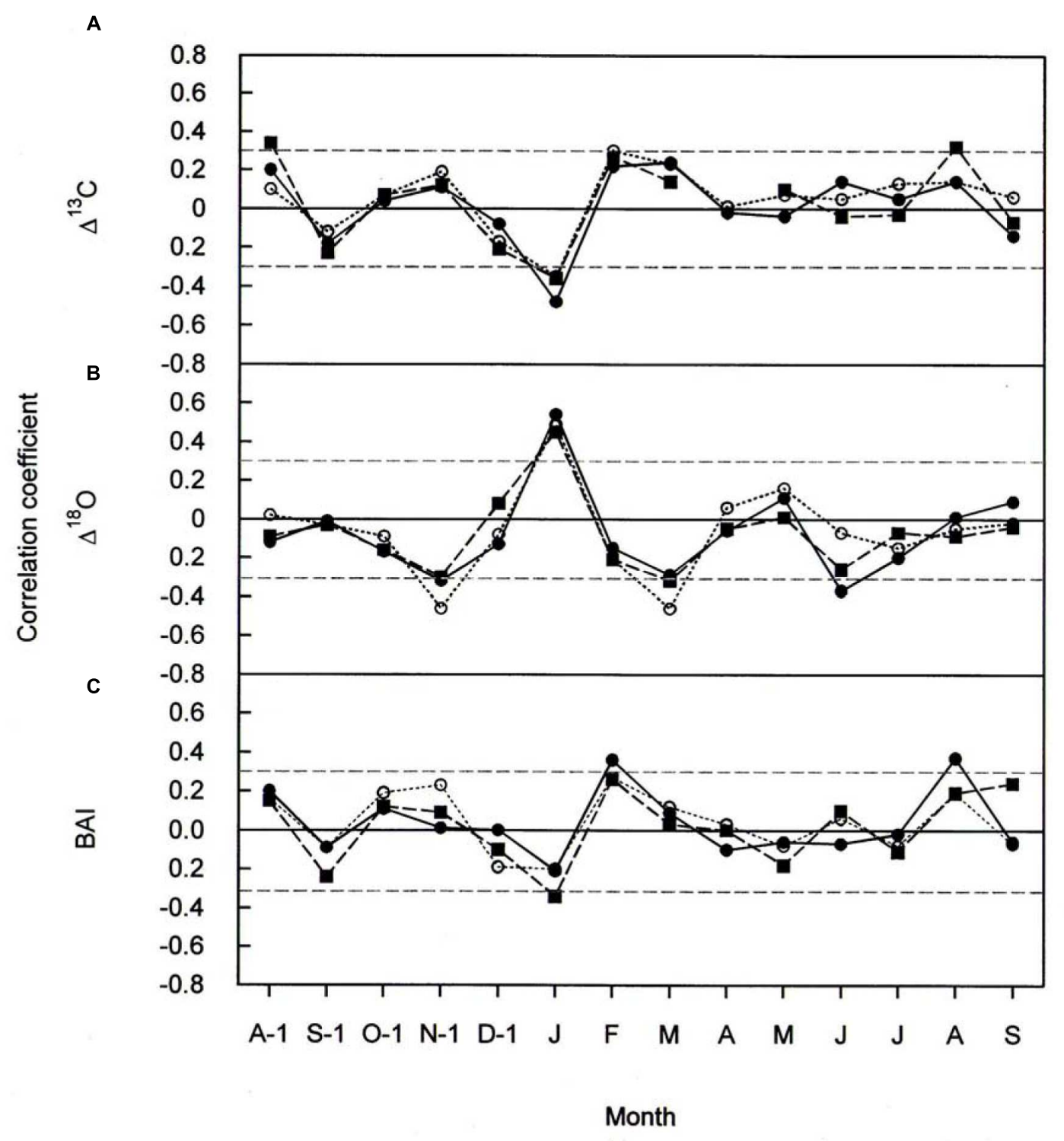

FIGURE 6 | Pearson correlation coefficients between (A) $\Delta^{13} C$ (B) $\Delta^{18} O$, and (C) BAl, and monthly total precipitation for $P$. cembra (solid circle, solid line), $P$. abies (solid square, dashed line) and $L$. decidua (open circle, dotted line) between $\mathbf{1 9 7 5}$ and 2010. Horizontal gray lines indicates $P<0.05$.

Beside climate warming and increasing $C_{\mathrm{a}}$, nitrogen deposition could also be important for explaining the observed increase in tree growth as increasing nitrogen deposition during the 1980ties (Smidt and Mutsch, 1993) has been suggested as a possible growth stimulator. However, there is evidence that nitrogen contents per needle dry mass are higher in trees at treeline as compared to trees growing at lower elevation sites (Körner, 1989; Birmann and Körner, 2009). Furthermore, since 1988, nitrogen deposition at treeline in the Tyrolean Alps is steadily declining (Amt der Tiroler Landesregierung, 2015), and a nitrogen fertilizer experiment at the alpine treeline in the Swiss Alps showed little or no growth stimulation (Keller, 1970). Thus, it seems that presently nitrogen deposition is insufficient to explain observed growth trends at treeline as reported previously by Tranquillini (1979) and Nicolussi et al. (1995).

\section{CONCLUSION}

Treeline trees respond to the increasing atmospheric $\mathrm{CO}_{2}$ level $\left(C_{\mathrm{a}}\right)$ in a way that their leaf-intercellular $\mathrm{CO}_{2}$ concentration $\left(C_{\mathrm{i}}\right)$ drifted upward paralleling the rise in atmospheric $\mathrm{CO}_{2}$ while iWUE remained stable over the last 36 years. The stability in iWUE was accompanied by an increase in BAI suggesting that treeline trees benefit from both recent climate warming) and $\mathrm{CO}_{2}$ fertilization. In addition, treeline trees are rarely forced to restrict 
transpiration due to ample soil water availability (Tranquillini, 1979; Matyssek et al., 2009; Wieser et al., 2015). A stable iWUE suggests an increase of both carbon gain and leaf conductance for water vapor as also indicated by stable $\mathrm{C}$ and $\mathrm{O}$ isotope analysis and direct gas exchange assessments. Furthermore, iWUE may not change species composition at treeline in the Austrian Alps due to similar ecophysiological responses to climatic changes of the three sympatric study species. Our finding that growth of treeline associated conifers increases with slowly rising ambient $\mathrm{CO}_{2}$ concentration and warming may be relevant for assessing complex growth models with empirical data, finally leading to model improvements and better estimations of forest-climate feedbacks.

\section{REFERENCES}

Amt der Tiroler Landesregierung (2015). Luftgüte in Tirol. Bericht über das Jahr 2014. Innsbruck: Amt der Tiroler Landesregierung.

Barbour, M. M. (2007). Stable oxygen isotope composition of plant tissue: a review. Funct. Plant Biol. 34, 83-94. doi: 10.1071/FP06228

Barbour, M. M., and Farquhar, G. D. (2000). relative humidity and ABA-induced variation in carbon and oxygen isotope ratios of cotton leaves. Plant Cell Environ. 23, 473-485. doi: 10.1046/j.1365-3040.2000.00575.x

Barbour, M. M., Fischer, R. A., Sayre, K. D., and Farquhar, G. D. (2000). Oxygen isotope ratio of leaf and grain material correlates with stomatal conductance and grain yield in irrigated wheat. Austr. J. Plant Physiol. 27, 625-637.

Barron-Gafford, G. A., Grieve, K. A., and Murthy, R. (2007). Leal-and standlevel responses of a forested mesocosm to independent manipulations of temperature and vapour pressure deficit. New Phytol. 174, 614-625. doi: 10.1111/j.1469-8137.2007.02035.x

Battipaglia, G., Saurer, M., Cherubini, P., Calfapietra, C., McCarthy, H. R., Norby, R. J., et al. (2013). Elevated $\mathrm{CO}_{2}$ increases tree-level intrinsic water use efficiency: insights from carbon and oxygen isotope analyses in tree rings across three forest FACE sites. New Phytol. 197, 544-554. doi: 10.1111/nph.12044

Benecke, U., Schulze, E.-D., Matyssek, R., and Havranek, W. M. (1981). Environmental control of $\mathrm{CO}_{2}$-assimilation and leaf conductance in Larix decidua Mill. I. a comparison of contrasting natural environmets. Oecologia 50, 54-61. doi: 10.1007/BF00378793

Bergh, J., and Linder, S. (1999). Effects of soil warming during spring on photosynthetic recovery in boreal Norway spruce stands. Glob. Change Biol. 5, 245-253. doi: 10.1046/j.1365-2486.1999.00205.x

Birmann, K., and Körner, C. (2009). Nitrogen status of conifer needles at the alpine treeline. Plant Ecol. Divers. 2, 233-241. doi: 10.1080/175508709034 73894

Borella, S., Leuenberger, M., Saurer, M., and Siegwolf, R. (1998). Reducing uncertainties in $\delta 13 \mathrm{C}$ analysis of tree rings: pooling, milling and cellulose extraction. J. Geophys. Res. 103, 519-526. doi: 10.1029/98JD01169

Brendel, O., Iannetta, P. P. M., and Stewart, D. (2000). Arapid and simple method to isolate pure alpha-cellulose. Phytochem. Anal. 11, 7-10. doi: 10.1002/(SICI) 1099-1565(200001/02)11:1<7::AID-PCA488> 3.0.CO;2-U

Brugnoli, E., and Farquhar, G. D. (2000). "Photosynthetic fractionation of carbon isotopes," in Photosynthesis: Physiology and Metabolism, Vol. 9, eds R. C. Leegood, T. D. Sharkey, and S. von Caemmerer (Dordrecht: Kluwer Academic Publishers), 399-434.

Bunn, A. G., Graumlich, L. J., and Urban, D. L. (2005). Trends in twentieth century tree growth at high elevations in the Sierra Nevada and White Mountains, USA. Holocene 15, 481-488. doi: 10.1191/0959683605hl827rp

Büntgen, U., Esper, J., Frank, D. C., Nicolussi, K., and Schmidhalter, M. (2005). A 1052-year tree-ring proxy for Alpine summer temperature. Clim. Dyn. 25, 141-153. doi: 10.1007/s00382-005-0028-1

Büntgen, U., Frank, D. C., Nievergelt, D., and Esper, J. (2006). Summer temperature variations in the European Alps, AD 755-2004. J. Clim. 19, 5606-5623. doi: $10.1073 /$ pnas. 1211485110

\section{AUTHOR CONTRIBUTIONS}

GW, RM, and TG conceived and designed the experiment. WO, AG, and ML performed the experiment. GW, WO, AG, and ML analyzed the data. GW, RM, and TG wrote the manuscript and $\mathrm{WO}$ and $\mathrm{AG}$ provided editorial advice.

\section{ACKNOWLEDGMENTS}

This work was supported by the Austrian Science Fund Project No. FWF P22206-B16 “Transpiration of conifers in contrasting environments." Thanks to the Umweltbundesamt Austria for providing us with annual mean $\delta^{18} \mathrm{O}$ data for Mt. Patscherkofel.

Carrer, M., and Urbinati, C. (2004). Age-dependent tree-ring growth response to climate in Larix decidua and Pinus cembra. Ecology 85, 730-740. doi: 10.1890/02-0478

Carrer, M., and Urbinati, C. (2006). Long-term change in the sensitivity of treering growth to climate forcing in Larix decidua. New Phytol. 170, 861-872. doi: 10.1111/j.1469-8137.2006.01703.x

Cernusak, L. A., Ubierna, N., Winter, K., Holtum, J. A. M., Marshall, J. D., and Farquhar, G. D. (2013). Environmental and physiological determinants of carbon isotope discrimination in terrestrial plants. New Phytol. 200, 950-965. doi: 10.1111/nph.12423

Danby, R. K., and Hik, D. S. (2007). Response of white spruce (Pinus glauca) to experimental warming at a subarctic alpine treeline. Glob. Change Biol. 13, 437-451. doi: 10.1111/j.1365-2486.2006.01302.x

Dawes, M. A., Hagedorn, F., Handa, I. T., Streit, K., Ekbald, Q. A., Rixen, C., et al. (2013). An alpine treeline in a carbon dioxide-rich world: synthesis of a nineyear free-air carbon dioxide enrichment study. Oecologia 171, 623-637. doi: 10.1007/s00442-012-2576-5

Duquesnay, A., Breda, N., Stievenard, M., and Dupouey, J. L. (1998). Changes of tree-ring $813 \mathrm{C}$ and water-use efficiency of beech (Fagus sylvatica L.) in northeastern France during the past century. Plant Cell Environ. 21, 565-572. doi: 10.1046/j.1365-3040.1998.00304.x

Farquhar, G. D., Ehleringer, J. R., and Hubick, K. T. (1989). Carbon isotope discrimination and photosynthesis. Annu. Rev. Plant Physiol. 40, 503-537. doi: 10.1146/annurev.pp.40.060189.002443

Farquhar, G. D., O'Leary, M. H., and Berry, J. A. (1982). On the relationship between carbon isotope discrimination and the intercellular carbon dioxide concentration in leaves. Aust. J. Plant. Physiol. 9, 121-137. doi: $10.1071 /$ pp9820121

Farquhar, G. D., and Richards, R. A. (1984). Isotopic composition of plant carbon correlates with water-use efficiency of wheat genotype. Aust. J. Plant. Physiol. 11, 539-552. doi: 10.1071/PP9840539

Flexas, J., Ribas-Carbo, M., Diaz-Espejo, A., Glamés, J., and Medrano, H. (2008). Mesophyll conductance to $\mathrm{CO}_{2}$ : current knowledge and future prospects. Plant Cell Environ. 31, 602-621. doi: 10.1111/j.1365-3040.2007. 01757.x

Frank, D., and Esper, J. (2005). Temperature reconstructions and comparisons with instrumental data from a tree-ring network for the European Alps. Int. J. Climatol. 25, 1437-1454. doi: 10.1002/joc.1210

Frank, D. C., Poulter, B., Saurer, M., Esper, J., Huntingford, C., Helle, G., et al. (2015). Water-use efficiency and transpiration across European forests during the Anthropocene. Nat. Clim. Change 5, 579-583. doi: 10.1038/NCLIMATE2614

Fritts, H. C. (1976). Tree Rings and Climate. London: Academic Presss.

Gessler, A., Brandes, E., Keitel, C., Boda, S., Kayler, Z., Granier, A., et al. (2013). The oxygen isotope enrichment of leaf-exported assimilates-does it always reflect lamina leaf water enrichment? New Phytol. 200, 144-157. doi: 10.1111/nph.12359

Grams, T. E. E., Kozovits, A. R., Häberle, K.-H., Matyssek, R., and Dawson, T. E. (2007). Combining $\delta 13 \mathrm{C}$ and $\delta 18 \mathrm{O}$ analyses to unravel competition, $\mathrm{CO}_{2}$ and 
$\mathrm{O}_{3}$ effects on the physiological performance of different-aged trees. Plant Cell Environ. 30, 1023-1034. doi: 10.1111/j.1365-3040.2007.01696.x

Graumlich, L. J. (1991). Subalpine tree growth, climate, and increasing $\mathrm{CO}_{2}$ : an assessment of recent growth trends. Ecology 72, 1-11. doi: 10.2307/19 38895

Graumlich, L. J., Brubaker, L. B., and Grier, C. C. (1989). Long-term growth trends in forest net primary productivity: cascade Mountains, Washington. Ecology 70 , 405-410. doi: 10.2307/1937545

Grissino-Mayer, H. D. (2001). Evaluating crossdating accuracy: a manual and tutorial for the computer program COFECHA. Tree Ring Res. 57, 205-221.

Gruber, A., Pirkebner, D., Oberhuber, W., and Wieser, G. (2011). Spatial and seasonal variations in mobile carbohydrates in Pinus cembra in the timberline ecotone of the Central Austrian Alps. Eur. J. Forest Res. 130, 173-179. doi: 10.1007/s10342-010-0419-7

Gruber, A., Wieser, G., and Oberhuber, A. (2009). Intra-annual dynamics in stem $\mathrm{CO} 2$ efflux in relation to cambial activity and xylem development in Pinus cembra. Tree Physiol. 29, 641-649. doi: 10.1093/treephys/tpp001

Havranek, W. M. (1981). Stammatmung, Dickenwachstum und Photosynthese einer Zirbe (Pinus cembra) an der Waldgrenze. Mitt Forstl. Bundesvers Wien. $142,443-467$.

Hoch, G., and Körner, C. (2003). The carbon charging of pines at the climatic treeline: a global comparison. Oecologia 135, 10-21. doi: 10.1007/s00442-002$1154-7$

Hoch, G., and Körner, C. (2012). Global patterns of mobie carbon stores in trees at the high-elevation tree line. Glob. Ecol. Biogeogr. 21, 861-871. doi: 10.1111/j.1466-8238.2011.00731.x

Holmes, R. L. (1994). Dendrochronology Program Library User's Manual. Laboratory of Tree-Ring Tucson: Research University of Arizona.

Holtmeier, F.-K., and Broll, G. (2007). Treeline advance - driving processes and adverse factors. Landscape 1, 1-33.

Jacoby, G. C., and D'Arrigo, R. D. (1997). Tree rings, carbon dioxide, and climate change. Proc. Natl. Acad. Sci. U.S.A. 94, 8350-8353. doi: 10.1073/pnas.94.16.8350

Jaggi, M., Saurer, M., Fuhrer, J., and Siegwolf, R. (2002). The relationship between the stable carbon isotope composition of needle bulk material, starch, and tree rings in Picea abies. Oecologia 131, 325-332. doi: 10.1007/s00442-0020881-0

Keller, T. (1970). Wuchsleistung, Gaswechsel, Überlebensprozente und Schneeschimmelpilzbefall gedüngter Ballenpflanzen an der oberen Waldgrenze. Mitt. Schweiz. Anstalt Forstl. Versuchsw. 46, 1-32.

Kellomäki, S., and Wang, K.-Y. (1998). Sap flow in Scots pines growing under conditions of year-round carbon dioxide enrichment and temperature elevation. Plant Cell Environ. 21, 969-981. doi: 10.1046/j.1365-3040.1998.00352.x

Körner, C. (1989). The nutrient status of plants from high altitude. A world-wide comparison. Oecologia 81, 379-391. doi: 10.1007/BF00377088

Kress, A., Saurer, M., Siegwolf, R. T. W., Frank, D., Esper, J., and Bugmann, H. (2011). A 350 year drought reconstruction from Alpine tree ring stable isotopes. Global Biogeochem. Cycles 24. doi: 10.1029/2009GB003613

Kunter, M., Nachtsheim, C., Neter, J., and Li, W. (2004). Applied Linear Statistical Models, 5th Edn. Irwin: McGraw-Hill.

Larcher, W. (2001). Ökophysiologie der Pflanzen: Leben, Leistung und Stressbewältigung der Pflanzen in ihrer Umwelt. Stuttgart: Ulmer.

Levesque, M., Siegwolf, R., Saurer, M., Eilmann, B., Brang, P., Bugmann, H., et al. (2014). Drought response of five conifer species under contrasting water availability suggests high vulnerability of Norway spruce and European larch. Glob. Change Biol. 19, 3184-3199. doi: 10.1111/gcb.12268

Liu, X., Wang, W., Xu, G., Zeng, X., Wu, G., Zhang, X., et al. (2015). Tree growth and intrinsic water-use efficiency of inland riparuian forests in norhwestern China: evaluation via $\delta 13 \mathrm{C}$ and $\delta 18 \mathrm{O}$ analysis of tree rings. Tree Physiol. 34, 966-980. doi: 10.1093/treephys/tpu067

Loader, N. J., McCarrol, D., Gagen, M., Robertson, I., and Jalkanen, R. (2007). "Extracting climatic information from stable isotopes in tree rings," in Stable Isotopes as Indicators of Ecological Change, eds T. E. Dawson and R. T. W. Siegwolf (London: Academic Press), 27-48.

Loris, K. (1981). Dickenwachstum von Zirbe, Fichte und Lärche an der alpinen Waldgrenze/Patscherkofel. Ergebnisse der Dendrometermessungen 1976/79. Mitt. Forstl. Bundesvers. Wien. 142, 417-441.
Marshall, J. D., and Monserud, R. A. (1996). Homeostatic gas-exchange parameters inferred from $13 \mathrm{C} / 12 \mathrm{C}$ in tree rings of conifers. Oecologia 105, 13-21. doi: $10.1007 / \mathrm{BF} 00328786$

Matyssek, R., Wieser, G., Patzner, K., Blaschke, H., and Häberle, K.-H. (2009). Transpiration of forest trees and stands at different altitude: consistencies rather than contrasts? Eur. J. Forest Res. 128, 579-596. doi: 10.1007/s10342-008-0243-5

Mayr, S. (2007). "Limits in water relations," in Trees at Their Upper Limit. Treelife Limitation at the Alpine Timberline, eds G. Wieser and M. Tausz (Dordrecht: Springer), $145-162$.

McCarrol, D., and Pawellek, E. (2004). Stable carbon isotope ratios of Pinus sylvestris from northern Finland and the potential for extracting a climate signal from long term Fennoscandian chronologies. Holocene 11, 517-526. doi: $10.1191 / 095968301680223477$

Neuwinger, I. (1972). Standortuntersuchungen am Sonnberg im Sellrainer Obertal, Tirol. Mitt. Forstl. Bundesvers. Wien. 96, 177-207.

Nicolussi, K., Bortenschlager, S., and Körner, C. (1995). Increase in tree-ring width in subalpine Pinus cembra from the centrak Alps may be $\mathrm{CO}_{2}$-related. Trees 9 , 181-189. doi: 10.1007/BF00195270

Oberhuber, W. (2004). Influence of climate on radial growth of Pinus cembra within the alpine timberline ecotone. Tree Physiol. 24, 291-301. doi: 10.1093/treephys/24.3.291

Oberhuber, W. (2007). "Limitation by growth processes," in Trees at Their Upper Limit. Treelife Limitation at the Alpine Timberline, eds G. Wieser and M. Tausz (Dordrecht: Springer), 131-143.

Oberhuber, W., Kofler, W., Pfeifer, K., Seeber, A., Gruber, A., and Wieser, G. (2008). Long-term changes in tree-ring-climate relationships at Mt. Patscherkofel (Tyrol, Austria) since the mid 1980s. Trees 22, 31-40. doi: 10.1007/s00468-0070166-7

Penuelas, J., Canadell, J. G., and Ogaya, R. (2011). Increased water-use efficiency during the 20th century did not translate into enhanced tree growth. Global Ecol. Biogeogr. 20, 597-608. doi: 10.1111/j.1466-8238.2010.00608.x

Peterson, D. L., Arbaugh, M. J., Robinson, L. J., and Dederian, B. I. (1990). Growth trends of whitebark pine and lodgepole pine in a subalpine Sierra Nevada forest, California, USA. Arct. Alp. Res. 22, 233-243. doi: 10.2307/1551586

Pilcher, J. R. (1990). "Sample preparation, cross-dating and measurement," in Methods of Dendrochronology: Applications in the Environmental Sciences, eds E. R. Cook and L. A. Kairiukstis (Dordrecht: Kluwer), 40-51.

Pisek, A., Larcher, W., Moser, W., and Pack, I. (1969). Kardinale Temperaturbereiche der Photosynthese und Grenztemperaturen des Lebens der Blätter verschiedener Spermatophyten. III. Temperaturabhängigkeit und optimaler Temperaturbereich der Netto-Photosynthese. Fora Ab. B 158, 608-630.

Pisek, A., Larcher, W., Vegis, A., and Napp-Zinn, K. (1973). "The normal temperature range," in Temperature and Life, eds H. Precht, J. Christophersen, H. Hensel, and W. Larcher (Berlin: Springer), 102-194.

Poage, M. A., and Chamberlain, C. P. (2001). Empirical relationships between elevation and stable isotope composition of precipitation and surface waters: considerations for studies of paleoelevation change. Am. J. Sci. 301, 1-15. doi: 10.2475/ajs.301.1.1

Roden, J. S., and Farquhar, G. D. (2012). A controlled test of the dual-isotope approach for the interpretation of stable carbon and oxygen isotope ratio variation in tree rings. Tree Physiol. 32, 490-503. doi: 10.1093/treephys/tps019

Rolland, C., and Florence-Schueller, J. (1998). Dendroclimatological synthesis on mountain pine (Pinus uncinata Mill. Ex Mirb.) in the Pyrenees and the Alps. Ecology 29, 417-421.

Sarris, D., Siegwolf, R., and Körner, C. (2013). Inter and intra-annual stable carbon and oxygen isotope signals in response to drought in Mediterranean pines. Agric. Forest Meteorol. 168, 59-68. doi: 10.1016/j.agrformet.2012.08.007

Saurer, M., Allen, K., and Siegwolf, R. T. W. (1997). Correlating $\delta 13 \mathrm{C}$ and $\delta 180$ in cellulose of trees. Plant Cell Environ. 20, 1543-1550. doi: 10.1046/j.13653040.1997.d01-53.x

Saurer, M., Cherubini, P., Reynolds-Henne, C. E., Treydte, K. S., Anderson, W. T., and Siegwolf, R. T. W. (2008). An investigation of the common signal in tree ring stable isotope chronologies at temperate sites. J. Geophys. Res. 113:G04035, doi: 10.1029/2008JG000689

Saurer, M., Spahni, R., Frank, D. C., Joos, F., Leuenberger, M., Loader, N. J., et al. (2014). Spatial variability and temporal trends in water-se efficiency of European forest. Glob. Change Biol. 20, 332-336. doi: 10.1111/gcb.12717 
Scheidegger, Y., Saurer, M., Bahn, M., and Siegwolf, R. (2000). Linking stable isotopes with stomatal conductance and photosynthetic capacity: a conceptual model. Oecologia 125, 350-357. doi: 10.1007/s004420000466

Seibt, U., Rajabi, A., Griffiths, H., and Berry, J. (2008). Carbon isotopes and water use efficiency: sense and sensitivity. Oecologia 155, 441-454. doi: 10.1007/s00442-007-0932-7

Sidorova, O. V., Siegwolf, R. T. W., Saurer, M., Shashkin, A. V., Knorre, A. A., Prokushkin, A. S., et al. (2009). Do centennial tree-ring and stable isotope trends of Larix gmelinii (Rupr.) indicate increasing water shortage in the Siberian north? Oecologia 161, 825-835. doi: 10.1007/s00442-0091411-0

Silva, L. C. R., and Anand, M. (2013). Probing for the influence of atmospheric $\mathrm{CO}_{2}$ and climate change on forest ecosystems across biomes. Glob. Ecol. Biogeogr. 22, 83-92. doi: 10.1111/j.1466-8238.2012.00783.x

Smidt, S., and Mutsch, F. (1993). "Messungen der nassen Freilanddeposition an alpinen Höhenprofilen," in Proceedings of the International Symposium 'Stoffeinträge aus der Atmosphäre und Waldbodenbe-Lastung in der Ländern der ARGE ALP und ALPEN ADRIA'. GSF-Report, Neuherberg, 21-29.

Sohn, J. A., Gebhardt, T., Ammer, C., Bauhus, J., Häberle, K.-H., Matyssek, R., et al. (2013). Mitigation of drought by thinning: short-term and long-term effects on growth and physiological performance of Norway spruce (Picea abies). Forest Ecol. Manag. 308, 188-197. doi: 10.1016/j.foreco.2013.07.048

Streit, K., Siegwolf, R. T. W., Hagedorn, F., Schaub, M., and Buchmann, N. (2014). Lack of photosynthetic or stomatal regulation after 9 years of elevated $\left[\mathrm{CO}_{2}\right]$ and 4 years of soil warming in two conifer species at the alpine treeline. Plant Cell Environ. 37, 315-326. doi: 10.1111/pce.12197

Tranquillini, W. (1979). Physiological Ecology of the Alpine Timberline. Tree Existence in High Altitudes with Special Reference to the European Alps. Ecological Studies 31. Berlin: Springer.

Treydte, K., Boda, S., Graf Pannatier, E., Fonti, P., Frank, D., Ullrich, B., et al. (2014). Seasonal transfer of oxygen isotopes from precipitation and soil to the tree ring: source water versus needle water enrichment. New Phytol. 202, 772-783. doi: 10.111/nph.12741

Treydte, K. S., Schleser, G. H., Schweingruber, F. H., and Winiger, M. (2001). The climatic significance of $\delta 13 \mathrm{C}$ in subalpine spruces (Lötschental. Swiss Alps). Tellus Ser. B 55, 593-611. doi: 10.1034/j.1600-0889.2001.530505.x

Van Herk, I. G., Gower, S. T., Bronson, D. R., and Tanner, M. S. (2011). Effect of climate warming on canopy water dynamics of a boreal black spruce plantation. Can. J. For. Res. 41, 217-227. doi: 10.1139/X10-196

Volgger, E. (1995). Zur Ozonempfindlichkeit der Europäischen Lärche (Larix decidua Mill.) an der Waldgrenze. Diploma thesis, Botany, University of Innsbruck, Innsbruck.

Weigt, R. B., Bräunlich, S., Zimmermann, L., Saurer, M., Grams, T. E. E., Dietrich, H.-P., et al. (2015). Comparison of $\delta 13 \mathrm{C}$ and $\delta 18 \mathrm{O}$ values between treering whole wood and cellulose in five species growing under two different site conditions. Rapid Commun. Mass Spectr. 29, 2233-2244. doi: 10.1002/ rcm.7388
Werner, C., Schnyder, H., Cuntz, M., Keitel, C., Zeeman, M. J., Dawson, T. E., et al. (2012). Progress and challenges in using stable isotopes to trace plant carbon and water relations across scales. Biogeosciences 9, 3083-3111. doi: 10.5194/bg-9-3083-2012

Wieser, G. (2004). Environmental control of carbon dioxide gas exchange in needles of a mature Pinus cembra tree at the alpine timberline during the growing season. Phyton 44, 145-153.

Wieser, G. (2012). Lessons from the timberline ecotone in the Central Tyrolean Alps: a review. Plant Ecol. Div. 5, 127-139. doi: 10.1080/17550874.2010.498062

Wieser, G., Gigele, T., and Pausch, H. (2005). Seasonal and spatial variation of woody tissue respiration in a Pinus cembra tree at the alpine timberline in the Central European Alps. Eur. J. For. Res. 124, 1-8. doi: 10.1007/s10342-0040050-6

Wieser, G., Grams, T. E. E., Matyssek, R., Oberhuber, W., and Gruber, A. (2015). Soil warming increased whole-tree water use of Pinus cembra at the treeline in the Central Tyrolean Alps. Tree Physiol. 35, 279-288. doi: 10.1093/treephys/tvp009

Wieser, G., Gruber, A., and Oberhuber, W. (2014). Sap flow characteristics and whole-tree water use of Pinus cembra across the treeline ecotone in the central Tyrolean Alps. Eur. J. For. Res. 133, 287-295. doi: 10.1007/s10342-013-0760-8

Wieser, G., and Leo, M. (2012). Whole tree water use by Pinus cembra at the treeline in the Central Tyrolean Alps. Plant Ecol. Div. 5, 81-88. doi: 10.1093/treephys/tpv009

Wieser, G., Matyssek, R., Luzian, R., Zwerger, P., Pindur, P., Oberhuber, W., et al. (2009). Effects of atmospheric and climate change at the timberline of the Central European Alps. Ann. For. Sci. 66:402. doi: 10.1051/forest/2009023

Wieser, G., Oberhuber, W., Walder, L., Spieler, D., and Gruber, A. (2010). Photosynthetic temperature adaptation of Pinus cembra within the timberline ecotone of the Central Austrian Alps. Ann. For. Sci. 67:201. doi: 10.1051/forest/2009094

Wu, G., Liu, X., Chen, T., Xu, G., Wang, W., Zeng, X., et al. (2015). Elevationdependent variations of tree growth and intrinsic water-use efficiency in Schrenk spruce (Picea schrenkiana) in the westen Tianshan Mountain, China. Front. Plant Sci. 6:309. doi: 10.3389/fpls.2015.00309

Zar, J. H. (1999). Biostatistical Analysis. Upper Saddle River, NJ: Prentice Hall.

Conflict of Interest Statement: The authors declare that the research was conducted in the absence of any commercial or financial relationships that could be construed as a potential conflict of interest.

Copyright (c) 2016 Wieser, Oberhuber, Gruber, Leo, Matyssek and Grams. This is an open-access article distributed under the terms of the Creative Commons Attribution License (CC BY). The use, distribution or reproduction in other forums is permitted, provided the original author(s) or licensor are credited and that the original publication in this journal is cited, in accordance with accepted academic practice. No use, distribution or reproduction is permitted which does not comply with these terms. 